Article

\title{
Efficient Solutions and Cost-Optimal Analysis for Existing School Buildings
}

\author{
Paolo Maria Congedo ${ }^{1}$, Delia D'Agostino ${ }^{2, *}$, Cristina Baglivo ${ }^{1}$, Giuliano Tornese ${ }^{1}$ \\ and Ilaria Zacà ${ }^{1}$ \\ 1 Department of Engineering for Innovation, University of Salento, 73100 Lecce, Italy; \\ paolo.congedo@unisalento.it (P.M.C.); cristina.baglivo@unisalento.it (C.B.); \\ giulianotornese2010@libero.it (G.T.); ilaria.zaca@gmail.com (I.Z.) \\ 2 Energy Efficiency and Renewables Unit, Energy, Transport and Climate Institute, \\ Joint Research Centre (JRC)—European Commission, 21027 Ispra (VA), Italy \\ * Correspondence: delia.dagostino@ec.europa.eu; Tel.: +39-033-278-3512 \\ Academic Editor: Chi-Ming Lai \\ Received: 14 July 2016; Accepted: 26 September 2016; Published: 21 October 2016
}

\begin{abstract}
The recast of the energy performance of buildings directive (EPBD) describes a comparative methodological framework to promote energy efficiency and establish minimum energy performance requirements in buildings at the lowest costs. The aim of the cost-optimal methodology is to foster the achievement of nearly zero energy buildings (nZEBs), the new target for all new buildings by 2020, characterized by a high performance with a low energy requirement almost covered by renewable sources. The paper presents the results of the application of the cost-optimal methodology in two existing buildings located in the Mediterranean area. These buildings are a kindergarten and a nursery school that differ in construction period, materials and systems. Several combinations of measures have been applied to derive cost-effective efficient solutions for retrofitting. The cost-optimal level has been identified for each building and the best performing solutions have been selected considering both a financial and a macroeconomic analysis. The results illustrate the suitability of the methodology to assess cost-optimality and energy efficiency in school building refurbishment. The research shows the variants providing the most cost-effective balance between costs and energy saving. The cost-optimal solution reduces primary energy consumption by $85 \%$ and gas emissions by $82 \%-83 \%$ in each reference building.
\end{abstract}

Keywords: school; buildings; retrofit; nearly zero energy buildings (nZEBs); cost-optimal methodology

\section{Introduction}

Buildings are a strategic focus of European policies aiming to achieve a sustainable and competitive low-carbon economy by 2020. The European Commission encourages member states (MS) to decrease energy consumption in buildings and convert national building stocks from energy consumers to energy producers through retrofit measures and renewable energy sources (RES). EU Directives require that public authorities should adopt exemplary actions to achieve this target.

A key policy instrument towards this goal is the Energy Efficiency Directive (EED), which includes provisions to increase energy efficiency at the European level [1]. In accordance with Article 24 (2) of the EED, MS are required from 2014, and then every three years, to submit National Energy Efficiency Action Plans (NEEAPs). NEEAPs shall cover energy efficiency improvement measures as well as expected and achieved energy savings, in view of attaining national targets referred to Article 3 (1).

Another central policy action is represented by the recast of the Energy Performance of Building Directive (EPBD) [2], which establishes that all new buildings have to be nearly zero energy buildings (nZEBs) by 31 December 2020 (Article 9). An nZEB can be achieved by combining high efficient technologies with RES [3]. 
Besides efforts to design new buildings having low energy demand and available RES [4-6], it is essential to tackle the high energy consumption in existing buildings. The contribution of buildings to the total final energy consumption in the EU was $40 \%$ in 2012, making the building stock responsible for $38 \%$ of the EU's total $\mathrm{CO}_{2}$ emissions [7]. Despite more stringent building codes and policies, which helped this value to decrease slightly in residential buildings since 2007, the final energy consumption in non-residential buildings remained quite stable in the last decade.

Improving and investing in energy renovation of the EU building stock is a key aspect not only for the derived savings and $\mathrm{CO}_{2}$ emissions reduction, but also for the potential growth and employment that this sector can provide [8]. According to the EPBD, MS have to consider cost-optimality to establish minimum energy performance requirements in buildings at the lowest costs. A methodology is provided by Delegated Regulation No. 244/2012 and its Guidelines to derive cost-effectiveness from a technical and economic perspective $[9,10]$. The methodology foresees a comparison in terms of costs [11] and energy performance [12] of construction alternatives to be taken into account both in new and existing buildings undergoing major or non-major renovation. The cost-optimal level is the solution that presents the lowest total costs and it can be located in the graph that reports global costs $\left(€ / \mathrm{m}^{2}\right)$ and energy consumption $\left(\mathrm{kWh} / \mathrm{m}^{2} \mathrm{y}\right)$ (Figure 1$)$.

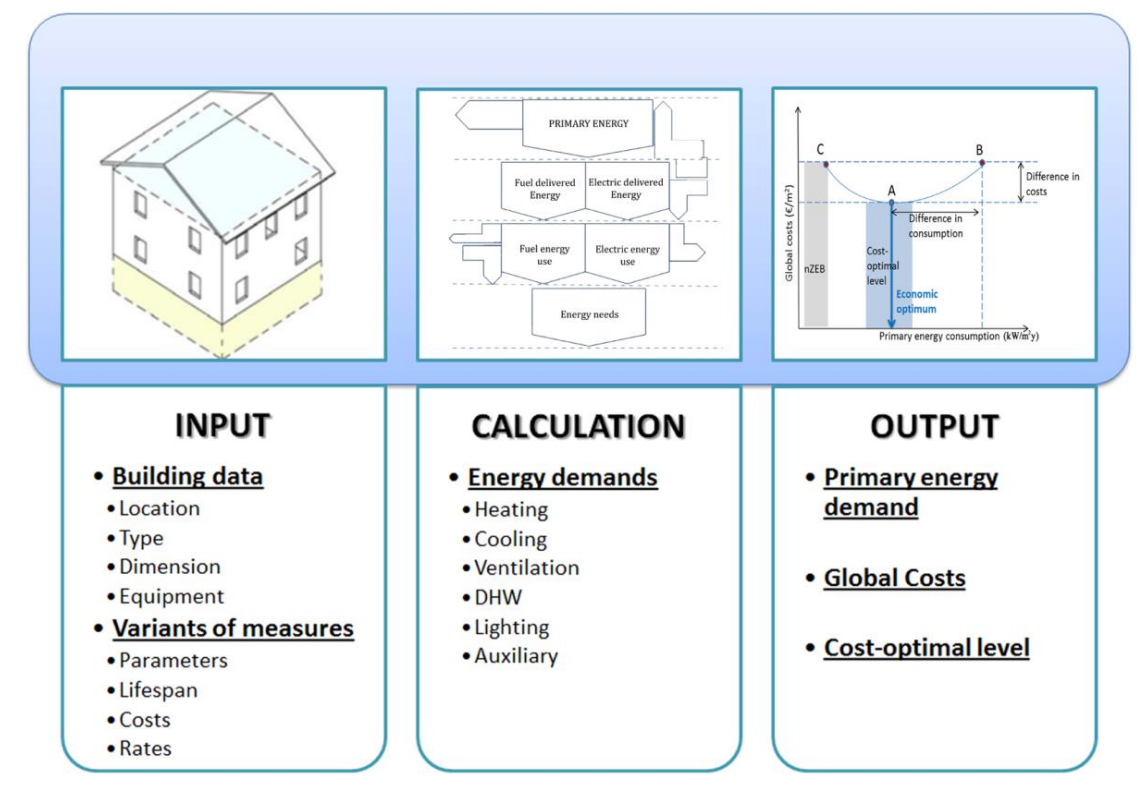

Figure 1. Steps involved in the cost-optimal methodology.

The cost-curve shape is influenced by different factors, such as building typology, variants, discount rate, energy price, and cost data. As a heterogeneous situation characterizes MS in relation to cost-optimal levels mainly depending on building types and climates [13], there is the need to develop the methodology for different reference buildings, regulations and conditions. In particular, cost-optimal results depend on the selected reference buildings (size, shape, compactness, proportion of window area).

This paper illustrates the application of the cost-optimal methodology to identify long-term efficient solutions for the renovation of school buildings located in the Mediterranean area. The reference cases shown in this paper are existing buildings located in two towns in the province of Lecce: Sanarica e Squinzano (Puglia Region, Southern Italy). The two reference buildings are described in terms of physical characteristics, envelope and systems. Then, a set of several combinations of refurbishment measures are identified as possible variants for both reference buildings. Energy performance and global costs are evaluated for the obtained combinations. The cost-optimal solution is identified in both cases considering a financial and macroeconomic analysis. The initial and the selected configurations are compared to calculate the related energy and $\mathrm{CO}_{2}$ savings. 
In conclusion, the main purpose of this paper is the identification of the strategies and optimal solutions for the renovation of existing buildings. The methodology presented helps the decisional and management process of the designers who want to guarantee comfort and cost-optimal solutions in school retrofitting, being a useful tool for municipalities at the same time. It shows how providing a reduction of energy consumption and greenhouse gas emission in a cost-effective way during building's lifecycle. Furthermore, the article aims to compensate for the lack of studies applied to the Mediterranean climate on public buildings.

The project focuses on the development and application of a new strategy for conducting complete techno-economic studies for energy refurbishment policy plans of public buildings. This approach can be useful to address EU requirements and develop energy management plans for public buildings.

\subsection{Cost-Optimal Studies Overview}

The majority of papers related to cost-optimality in the literature are related to new buildings [14]. In previous studies $[15,16]$, the authors of this research investigate new mono and multi residential buildings as well as office buildings located in the Mediterranean climate [17]. The research showed that cost-optimal solutions reduce primary energy consumption between $68 \%$ and $95 \%$ compared with the reference scenario. Obtaining nZEBs taking into account cost-optimality is still challenging and often limited to demonstration studies or pilot projects. However, the potential reduction of the environmental impact of new buildings is negligible compared to that of existing ones [18-22]. The analysis of several energy renovation packages in a given building and the evaluation of the related costs in two different economic scenarios are useful to derive the optimal solution both in terms of energy performance and global costs [23].

The design of a building energy retrofit is a challenging task that requires a holistic and integrated approach with the two main objectives of energy consumption minimization and economic benefits maximization [24].

The increasing requirements of building quality improvement are the aim of many studies. New approaches are considered to quantify the added value created for the owners of the building by investment in renovation via energy-saving investments that produce positive externalities [25].

Public buildings, such as offices and schools, are typically characterized by a higher lighting and electric demand, increased ventilation needs and heat gains due to occupants [26]. As a consequence, heating, cooling, lighting and electric uses impact annual primary energy consumption, while in residential buildings space heating is usually the largest energy need. The challenge of designers implies major issues in retrofit project strategies, which has to take into account environmental, sociocultural and economic criteria at the same time.

A review of building energy retrofit is proposed by Ma et al. [27]. The authors consider two buildings types that usually cover the majority of the stock of a country: residential and office buildings. They show the difference between the best energy retrofit packages in case of heterogeneous building types.

The Buildings Performance Institute Europe has published an overview on the implementation of the cost-optimal methodology in Austria, Germany and Poland [28]. Multi-family and single-family buildings have been studied to demonstrate that energy performance requirements in buildings are ambitious but affordable. A study on cost-optimality in eight existing primary schools located in the Alps (Tyrol, Austria) was carried out in [29]. The research demonstrates that building age and investment costs have an important impact on the results. In particular, the choice of the thermal insulation, thickness and conductivity, addresses the right selection of the thermal properties of windows, in order to reach a compromise between the performance and investment costs, which is still a debated issue at EU level.

In relation to public buildings and in particular schools, a study on energy consumption and potential savings has been carries out in Italy by National Energy Agency (ENEA) [30]. This study has applied the cost-optimal methodology for retrofit interventions in virtual existing office and school 
buildings located in Rome (climatic zone D) and Milan (climatic zone E) [31]. Results show that the heating demand is higher in Milan than in Rome so the cost saving is more effective in the first one, considering a 30-year calculation period.

\subsection{Italian Policy Framework}

Italy has implemented the EPBD and its recast at national level with Legislative Decree 192/05 and with the Decree Law 63/13, converted into law by Law 90/13. The Ministerial Decree of 26 June 2015 defines the methodologies for calculating energy performance and the minimum energy requirements in buildings [32]. Furthermore, National Law 10/91 gives a comprehensive framework related to energy efficiency in buildings providing explicit regulations for a more efficient use of energy sources in all end-use sectors.

At national level, the measure of the energy performance of a building (Epi) indicates how much energy a building consumes during a year per square meter of treated floor area (TFA). The Epi of an existing building built before national Law 10/91 is generally between 200 and $300 \mathrm{kWh} / \mathrm{m}^{2} \mathrm{y}$ with fuel consumption between 10 and $30 \mathrm{~L}$ oil $/ \mathrm{m}^{2} \mathrm{y}$. The Epi of a building designed and built according to current legislation is between 15 and $130 \mathrm{kWh} / \mathrm{m}^{2} \mathrm{y}$ with fuel consumptions between 1.5 and $13 \mathrm{~L}$ oil $/ \mathrm{m}^{2} \mathrm{y}$.

At regional level, the Puglia Region promotes environmental sustainability and energy saving in urban renovation as well as in the construction of public and private buildings with the Legislative Decree No. 13 of 10 June 2008. This law defines the tools, techniques and construction methods both for new and existing buildings. The promotion of the requalification of existing buildings is the goal of the Regional Regulation No. 10 of 10 February 2010. It contains the methodology for calculating energy performance of buildings and energy certification. An energy performance certificate includes the reference performance of a building and other reference values. As regards climate, Italy is divided into six climatic zones (from A, having up to 600 degree days, to F, having more than 3001 degree days).

Italy submitted its report on cost-optimality, coordinated by the Ministry for the Economic Development, in August 2013 [30]. The methodology has been applied to new and existing (from 1946 to 1976 and from 1977 to 1990) residential and non-residential buildings located in three cities of different climatic zones: Milan (climatic zone E), Rome (climatic zone D) and Palermo (climatic zone B). Moreover, the climatic zone $\mathrm{C}$, where the buildings of this study are located, is not included in the previous study. This climate is characterized by a Mediterranean climate with non-extreme winters and high aridity in summer (Lecce has 1153 heating-degree-days).

\subsection{School Buildings in Italy}

\subsubsection{The National School Stock}

Non-residential buildings represent around 13\% of the Italian building stock [7]. In particular, there are around 51,000 buildings entirely or partly used as schools [33]. With regard to their location, $30 \%$ of school buildings are concentrated in 10 provinces, such as Rome, Milan and Naples, and more than half (51\%) are situated in 24 provinces. Furthermore, about $29 \%$ of schools are located in very small municipalities (up to 5000 inhabitants), and roughly the same percentage are in medium sized municipalities. The overall floor area of school buildings is 73.2 million $\mathrm{m}^{2}$ and their total volume is around 256.4 million $\mathrm{m}^{3}$. The largest share of school buildings (39\%) has a floor area between 1000 and $3000 \mathrm{~m}^{2}$, with an average area of $1819 \mathrm{~m}^{2}$. In more detail, $43 \%$ of school buildings can be broken down by floor area as follows: 16\% have a floor area between 751 and $1000 \mathrm{~m}^{2}$ (average $899 \mathrm{~m}^{2}$ ), 14\% between 501 and $750 \mathrm{~m}^{2}$ (average $631 \mathrm{~m}^{2}$ ) and 13\% between 351 and $500 \mathrm{~m}^{2}$ (average $435 \mathrm{~m}^{2}$ ).

The majority of existing school buildings present inefficient systems and technologies. They often use traditional heating systems, in particular radiators for heat distribution and gas/oil-fired boilers for generation [34]. Space heating is still the main end-use with $43 \%$ of heating needs met using natural gas in 2012. 
It is estimated that Italian public school students number about 7.5 million with 0.9 million teachers. Considering students, teachers and parents, more than a quarter of the Italian population attends a school building daily [35].

Existing schools and the majority of refurbished schools are not provided with HVAC (Heating ventilation and air conditioning), leading to inadequate air change rates, representing a critical problem, because poor indoor air quality leads to loss attention and health within classrooms $[36,37]$. School holidays in Mediterranean countries are mainly in summer and this is why the majority of schools do not have a cooling system, presenting frequent comfort issues. Therefore, a key aspect in Southern European countries is maintaining proper air quality and comfort levels. The most commonly used technologies to reduce cooling energy demand in the Mediterranean area are: solar control features (e.g., mobile or fixed shading devices and structures, including verandas); night ventilation; ground-coupled heat exchanger for pre-cooling of ventilation air; ventilation systems with summer mode (bypass of heat exchanger). Reversible heat pumps are a common solution where mechanical cooling is needed. To reduce heating needs, buildings need to be insulated and heating systems replaced with efficient technologies, and RES encouraged if feasible.

Possible strategies to reduce energy consumption in public schools have also been investigated in [38]. The environmental benefit achievable over 20 years through refurbishment actions on plants and envelopes have been estimated. The research also compares the costs of standard retrofit interventions to the benefits achievable in terms of energy and money saving through a payback time analysis that identifies priorities of intervention.

\subsubsection{Potential Savings from School Buildings}

Energy saving that can be derived from improvements to existing school buildings are potentially large because of their typical high energy consumption linked to inefficient systems and poor thermal insulation thickness. With the aim of improving energy efficiency in public buildings (e.g., offices, schools, health facilities, infrastructures), energy services companies (ESCOs) are being more common nationally.

A study has been carried out on the potential savings deriving from energy retrofit in schools in compliance with the EED [39]. Potential savings refer to the saving achievable if, in the period 2014-2020, energy efficiency actions would be put into practice with a cost-optimal approach to achieve saving of $60 \%$ in the public sector and $40 \%$ in the private sector. To assess these potential savings, the Italian school building stock has been analyzed. The floor area of public and private schools that can be renovated each year has been estimated at 6 million $\mathrm{m}^{2}$ (about 3800 buildings). This total includes about 1 million $\mathrm{m}^{2}$ private schools and 5 million $\mathrm{m}^{2}$ public schools (Table 1 ).

Table 1. Consumption reduction potential by 2020 from complete renovation of schools starting from 2014.

\begin{tabular}{cccc}
\hline Buildings & $\begin{array}{c}\text { Floor Area Covered by } \\
\text { Renovation Each Year }\left(\mathbf{m}^{2}\right)\end{array}$ & $\begin{array}{c}\text { Total Energy Savings } \\
\text { by } \mathbf{2 0 2 0}(\mathbf{G W h} / \mathbf{y})\end{array}$ & $\begin{array}{c}\text { Total Energy Savings } \\
\text { by 2020 (Mtoe/y) }\end{array}$ \\
\hline Private schools & $1,000,000$ & 617 & 0.05 \\
Public schools & $4,950,000$ & 5821 & 0.50 \\
Total & $5,950,000$ & 6438 & 0.55 \\
\hline
\end{tabular}

For this stock, the study considers actions differentiated by climatic zone and applicability. Among them there are: thermal insulation of roof and heat-dispersing external walls, thermal insulation of stilt floors or floors/ceilings bordering on unheated spaces, replacement of existing windows with high-energy performance windows, upgrading heating/cooling control systems, replacement of heat generators, use of high-efficiency heat recovery systems, installation of automation systems or a building energy management system (BEMS), replacement of lighting and external solar screens.

Specifically, the total energy savings achievable from schools by 2020 are estimated as follows: $617 \mathrm{GWh} / \mathrm{y}$ for private schools (0.05 Mtoe/y) and $5821 \mathrm{GWh} / \mathrm{y}$ for public schools (0.5 Mtoe/y). 
The difference in energy saving percentages between public and private sectors stems from the fact that public buildings are mainly constructed prior to 1980 and their starting energy performance is poorer. The estimated investments for these retrofit projects amount to around 6.54 billion $€ / y$, and should yield potential energy savings of $6.438 \mathrm{GWh} / \mathrm{y}$, equivalent to $0.55 \mathrm{Mtoe} / \mathrm{y}$, by 2020. At European level, the added value deriving from specialized construction activities that include renovation work and energy retrofits has been estimated as 283 billion $€$ in $2011,66 \%$ of this value is linked to the EU building sector. In particular, specialized construction activities supported 7.84 million jobs in the EU building sector, and 1.55 million in Italy. In more detail, activities linked to building envelope (e.g., roofing, walls and floor covering, glazing) have been quantified at 166 billion in the same year [33].

\subsubsection{Financial Instruments to Renovate School Buildings}

Schools are among the most common spaces in which various users coexist. Therefore, schools have to ensure a suitable environment, also for health, comfort and productivity concerns.

In the last few years, relevant funding opportunities have been allocated for school buildings by the EU. Many projects have been funded, such as the EU FP7 projects School of the Future and the IEE ZEMedS [40,41].

In relation to financial instruments dedicated to schools in Italy, the Decree Law No. 104/2013 (http://www.gazzettaufficiale.it/eli/id/2013/09/12/13G00147/sg) and the Economy and Finance Document (DEF) of 2014 have introduced some measures to enable Italian regions to establish loans with the European Investment Bank (EIB) and other banks [42]. To encourage investments in school buildings, 40 million $€$ per year are available from 2015. Moreover, the structural funds 2014-2020 also includes a budget for renovating and upgrading schools. The Ministry of Education, University and Research has allocated 38 million $€$ for new schools and it will cover up to $25 \%$ of their construction costs. The same Ministry has assigned 150 million $€$ for renovation and safety upgrading of schools. As at the end of March 2014, 462 projects had been funded. Projects focused on promoting energy efficiency in schools are increasing in Italy. The National Registry of School Buildings is collecting data and procedures while an observatory verifies the projects effectiveness and planning.

Among these projects, there are: "Energy saving starts at school" in the Piedmont Region, and "Learning about energy saving and the development of renewable sources-New ideas in the classroom", involving 147 middle schools (children aged 11-13). This project included a survey to collect information on initiatives implemented in secondary schools for energy saving and RES. It also includes a competition of suggestions, such as "Tell me about your energy". Sixteen hundred middle school children participated, submitting essays on this theme. Environmental sustainability awareness is also promoted in schools via the "Smart School" plan, which aims to engage the education system in the building of a "smart city". Many other projects in schools related to the installation of photovoltaic plants, heat pumps and geothermal energy systems or the promotion of a more rational energy use.

Specific actions targeting schools are related to initiatives to increase energy-awareness in daily behaviors. These actions are aimed at strengthening communication on energy efficiency and the improvement of the user-friendliness and transparency of information as part of an integrated plan for the uptake of energy efficiency.

\section{Methodology}

The study presented in this paper has been carried out in accordance with the EPBD recast [2] the Delegated Regulation [9] and its Guidelines [10]. The methodology is based on a comparative framework that comprises existing buildings undergoing major and non-major renovation of structural and technical components. In particular, the methodology consists of several steps that include:

- Definition of reference buildings;

- Establishment of energy efficiency measures (measures based on energy from RES and/or packages and variants of such measures for each reference building);

- Calculation of primary energy demand resulting from the application of the previously selected measures and/or packages of measures; 
- Calculation of global costs in terms of net present value for each reference building;

- Sensitivity analysis related to cost data;

- Identification of cost-optimal levels in each reference building.

\subsection{The Reference Buildings}

In relation to reference buildings, MS can select different types of non-residential buildings as listed in Annex I (paragraph 5) of the EPBD recast [2]. For each category, at least one reference building has to be defined for new buildings and two for existing buildings undergoing complete renovation. The latter ones can be selected on the basis of subcategories (e.g., size, age, costs, construction materials, use or climatic zone) taking into account national building stock characteristics.

The reference scenario is a reference building with the boundary conditions that characterize the object of the study. In particular, it represents a typical and average building stock in a given Member State, because it is impossible to calculate the optimal situation under the cost profile for each individual building. For this reason, the reference buildings will define as closely as possible the actual national building stock, so that the calculation methodology provides representative results. Reference buildings have to respect existing or planned energy performance requirements.

In this paper, two existing school buildings have been investigated. As previously stated, the Mediterranean area to which they belong is characterized by mild winters and hot dry summers [42,43]. This climate is common in Southern Italy (e.g., Puglia, Sicily, and Calabria regions) and Southern Europe (e.g., Cyprus, Greece, Spain, and Portugal). At national level, the area falls within the climatic zone $\mathrm{C}$ that has not yet been addressed in [30]. In this area, the indoor design temperature of a building is $20^{\circ} \mathrm{C}$ during the heating period, running from 15 November to $31 \mathrm{March}$, and $26^{\circ} \mathrm{C}$ during the cooling period [44]. The structures of the case studies are different depending on period of construction, size and final users (Table 2).

Table 2. Construction properties and element data set of reference building 1 (REF1).

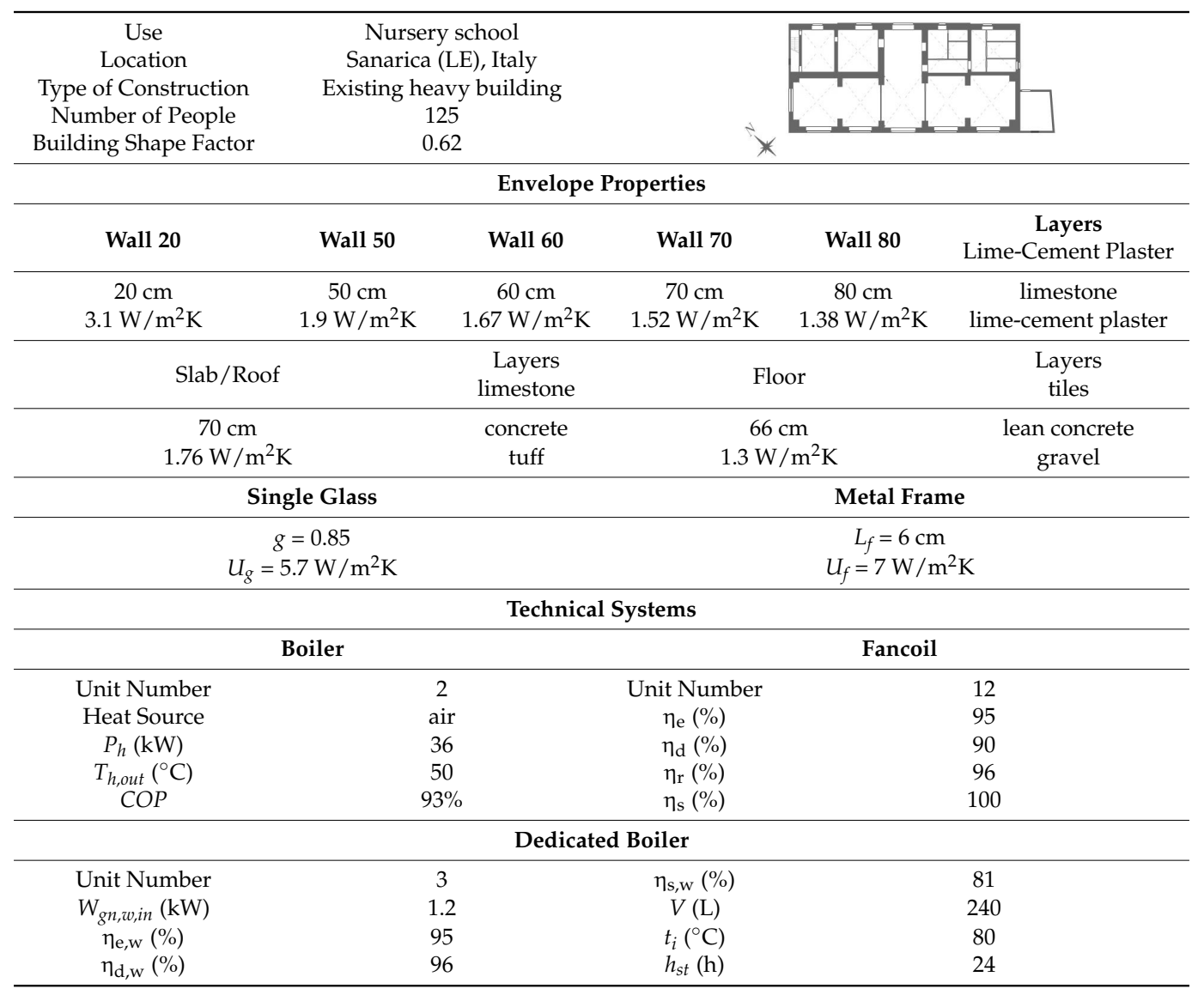


The first reference building, REF1, is a nursery school located in Sanarica (province of Lecce). Its main facade is oriented towards the Northeast. The gross heated volume is equal to $1728.07 \mathrm{~m}^{3}$ and the dissipating area is $1066.56 \mathrm{~m}^{2}$, with a shape factor of 0.62 . The envelope of the building has the typical features of the period in which it was built (presumably between 1950 and 1960). In particular, the masonry consists of tuff blocks (and/or limestone) with an average thickness of $60 \mathrm{~cm}$. The roof is characterized by typical star and barrel vaults. The window frames (including doors) are in aluminum with single glazing without shutters. Heating is provided by two natural gas boilers with a power of $36 \mathrm{~kW}$ (each) with fancoils. Hot water is produced exclusively by three electric boilers placed in bathrooms and utility rooms. There are cooling and ventilation systems. The building can accommodate 125 users, considering nine months (from September to May) of activity. Internal heat gains, sensible and latent heat emitted within an internal space by occupants, are estimated to $4 \mathrm{~W} / \mathrm{m}^{2}$.

The second reference building, REF2, is a kindergarten school located in Squinzano (province of Lecce). It is oriented in a northeasterly direction and it was built around 1977 (Table 3).

Table 3. Construction properties and element data set of the reference building in Squinzano (REF2).

\begin{tabular}{|c|c|c|c|c|c|}
\hline \multicolumn{3}{|c|}{ Kindergarten school } & & & \\
\hline Location & \multicolumn{2}{|c|}{ Squinzano (LE), Italy } & & 17 & \\
\hline $\begin{array}{c}\text { Type of } \\
\text { Construction }\end{array}$ & \multicolumn{2}{|c|}{ Existing heavy building } & & & \\
\hline Number of People & \multicolumn{2}{|l|}{350} & & 七4 & \\
\hline $\begin{array}{l}\text { Building Shape } \\
\text { Factor }\end{array}$ & \multicolumn{2}{|l|}{0.73} & $x$ & + & \\
\hline \multicolumn{6}{|c|}{ Envelope Properties } \\
\hline Wall 30 & $\begin{array}{c}\text { Layers } \\
\text { Lime cement plaster }\end{array}$ & Slab/Roof & $\begin{array}{c}\text { Layers } \\
\text { Lime plaster and gypsum }\end{array}$ & Floor & $\begin{array}{c}\text { Layers } \\
\text { linoleum }\end{array}$ \\
\hline $30 \mathrm{~cm}$ & & $33 \mathrm{~cm}$ & $\begin{array}{l}\text { Floor with joists and concrete } \\
\text { blocks and concrete topping }\end{array}$ & $61 \mathrm{~cm}$ & $\begin{array}{c}\text { screed lightened } \\
\text { with expanded clay }\end{array}$ \\
\hline $1.37 \mathrm{~W} / \mathrm{m}^{2} \mathrm{~K}$ & $\begin{array}{l}\text { Perforated brick } \\
\text { Plastic plaster }\end{array}$ & $1.66 \mathrm{~W} / \mathrm{m}^{2} \mathrm{~K}$ & $\begin{array}{l}\text { bituminous waterproofing } \\
\text { membrane with aluminum }\end{array}$ & $1.12 \mathrm{~W} / \mathrm{m}^{2} \mathrm{~K}$ & $\begin{array}{l}\text { standard concrete } \\
\text { gravel }\end{array}$ \\
\hline \multicolumn{2}{|c|}{ Single Glass } & \multicolumn{2}{|c|}{ Double Glass $(\Psi=0.11 \mathrm{~W} / \mathrm{mK})$} & \multicolumn{2}{|c|}{ Metal Frame } \\
\hline \multicolumn{2}{|c|}{$\begin{array}{c}g=0.85 \\
U_{g}=5.7 \mathrm{~W} / \mathrm{m}^{2} \mathrm{~K}\end{array}$} & \multicolumn{2}{|c|}{$\begin{aligned} & g=0.71 \\
U_{g}= & 3.17 \mathrm{~W} / \mathrm{m}^{2} \mathrm{~K}\end{aligned}$} & \multicolumn{2}{|c|}{$\begin{array}{c}L_{f}=6 \mathrm{~cm} \\
U_{f}=7 \mathrm{~W} / \mathrm{m}^{2} \mathrm{~K}\end{array}$} \\
\hline \multicolumn{6}{|c|}{ Technical Systems } \\
\hline \multicolumn{3}{|c|}{ Boiler } & \multicolumn{3}{|c|}{ Radiator } \\
\hline Unit Number & 1 & & Unit Number & & 12 \\
\hline Heat Source & air & & $\eta_{\mathrm{e}}(\%)$ & & 92 \\
\hline$P_{h}(\mathrm{~kW})$ & 140 & & $\eta_{d}(\%)$ & & 95 \\
\hline$T_{h, \text { out }}\left({ }^{\circ} \mathrm{C}\right)$ & 80 & & $\eta_{\mathrm{r}}(\%)$ & & 94 \\
\hline COP & $88 \%$ & & $\eta_{\mathrm{s}}(\%)$ & & 100 \\
\hline \multicolumn{6}{|c|}{ Domestic Hot Water: Combined Heating } \\
\hline \multicolumn{2}{|c|}{$\eta_{\mathrm{e}, \mathrm{w}}(\%)=95$} & \multicolumn{2}{|r|}{$\eta_{\mathrm{d}, \mathrm{w}}(\%)=96$} & \multicolumn{2}{|c|}{$\eta_{\mathrm{s}, \mathrm{w}}(\%)=100$} \\
\hline
\end{tabular}

The bearing structure of the building consists of pillars and beams in reinforced concrete. The external walls have perforated bricks in cement and expanded clay with a thickness of about $27 \mathrm{~cm}$ while internal walls are about $10 \mathrm{~cm}$ thick. The cover consists of reinforced concrete slabs having a thickness of about $25 \mathrm{~cm}$, supplied with a waterproof bituminous sheath. The external and internal window frames are made of a special colored steel of double glazing in the external part and single glazing in the internal. The heating system consists of a black steel piping, radiators are cast iron and the natural gas generator has an output power of $127 \mathrm{~kW}$. For all areas, the air and light supply is directed and cover at least $1 / 8$ of the floor area. Generally, the nursery opening hours range from 6 to $8 \mathrm{~h}$ per day, so air conditioning systems have a working period of about $1500 \mathrm{~h}$ per year. There is no mechanical ventilation system, therefore the air change is exclusively natural and manual. The building can accommodate 367 users with internal heat gains of $4 \mathrm{~W} / \mathrm{m}^{2}$ per person. 


\subsection{Retrofit Variants and Combinations}

Different types of energy efficiency measures (EEMs) have been selected both for the envelope and technical systems; the combination of EEMs, derived from a matrix calculation, has defined several solutions for each reference building.

The first analysis has been carried out for the reference building located in Sanarica (REF1) with 288 combinations. Then 96 combinations have been analyzed for the reference building located in Squinzano (REF2). The solutions have been obtained combining the considered variants for each building. In particular, the analysis has been made taking into account the substitution of the old windows, metal frames without thermal breaks and single glazing, and the application of an insulation and a thermal plaster for the external walls. The efficiency of the envelope has been included in the cover slab and the floor. In Table 4 the variants for the envelope of both buildings are reported.

Table 4. Variants of insulating for external walls and variants of windows of the reference buildings.

\begin{tabular}{|c|c|c|c|c|c|c|}
\hline \multirow{2}{*}{ ID } & \multirow{2}{*}{ Material } & \multirow{2}{*}{ Type } & \multirow{2}{*}{$\begin{array}{c}\lambda \\
\mathrm{W} / \mathrm{mK}\end{array}$} & \multirow{2}{*}{$\begin{array}{c}c \\
\mathrm{~J} / \mathrm{KgK}\end{array}$} & \multirow{2}{*}{$\frac{\rho}{\mathrm{kg} / \mathrm{m}^{3}}$} & \multirow{2}{*}{$\frac{d}{\mathrm{~mm}}$} \\
\hline & & & & & & \\
\hline $\begin{array}{l}\text { REF1_INS01 } \\
\text { REF1_INS02 } \\
\text { REF1_INS03 }\end{array}$ & Wood fiber hardboard & natural insulating & 0.039 & 2100 & 160 & $\begin{array}{c}60 \\
80 \\
100\end{array}$ \\
\hline $\begin{array}{l}\text { REF1_INS04 } \\
\text { REF1_INS05 } \\
\text { REF1_INS06 }\end{array}$ & Cork panels expanded & natural insulating & 0.038 & 1900 & 120 & $\begin{array}{c}60 \\
80 \\
100\end{array}$ \\
\hline $\begin{array}{l}\text { REF1_INS07 } \\
\text { REF1_INS08 } \\
\text { REF1_INS09 }\end{array}$ & Hemp fibers & natural insulating & 0.030 & 2200 & 38 & $\begin{array}{c}60 \\
80 \\
100\end{array}$ \\
\hline $\begin{array}{l}\text { REF1_INS10 } \\
\text { REF1_INS11 } \\
\text { REF1_INS12 }\end{array}$ & Polyurethane foam & no natural insulating & 0.023 & 1255 & 36 & $\begin{array}{c}60 \\
80 \\
100\end{array}$ \\
\hline REF2_INS01 & Polyurethane foam & no natural insulating & 0.023 & 1255 & 36 & 60 \\
\hline REF2_INS02 & Hemp fibers panles & natural insulating & 0.030 & 2200 & 38 & 60 \\
\hline \multicolumn{7}{|c|}{ Plaster } \\
\hline $\begin{array}{l}\text { REF1_PL01 } \\
\text { REF2_PL01 }\end{array}$ & Natural hydraulic lime & plaster & \multirow[t]{2}{*}{0.086} & \multirow[t]{2}{*}{1000} & 410 & 40 \\
\hline \multicolumn{5}{|c|}{ Variants of Windows } & & \\
\hline REF1_WI01 & glass & \multicolumn{2}{|c|}{$\begin{array}{l}\text { stratified double insulated } \\
\text { glass with coating }\end{array}$} & $\begin{array}{c}3-3 / 12 / 3-3 \\
g=0.30\end{array}$ & \multicolumn{2}{|c|}{$U_{g}=1.123 \mathrm{~W} / \mathrm{m}^{2} \mathrm{~K}$} \\
\hline REF2 WI01 & frame & metal with thermal bre & & $L_{f}=10 \mathrm{~cm}$ & $U_{f}=2$ & $/ \mathrm{m}^{2} \mathrm{~K}$ \\
\hline & spacer & metal & & $\mathrm{s}=12 \mathrm{~mm}$ & $\Psi=0$ & $\mathrm{~V} / \mathrm{mK}$ \\
\hline REF1_WI02 & glass & $\begin{array}{l}\text { stratified double insula } \\
\text { glass with coating }\end{array}$ & & $\begin{array}{c}3-3 / 12 / 3-3 \\
g=0.30\end{array}$ & $U_{g}=1.1$ & $\mathrm{~N} / \mathrm{m}^{2} \mathrm{~K}$ \\
\hline REF2 WI02 & frame & wood & & $L_{f}=10 \mathrm{~cm}$ & $U_{f}=1$. & $/ \mathrm{m}^{2} \mathrm{~K}$ \\
\hline & spacer & metal & & $\mathrm{s}=12 \mathrm{~mm}$ & $\Psi=0$ & $\mathrm{~J} / \mathrm{mK}$ \\
\hline
\end{tabular}

Twelve types of insulation for external walls have been considered for REF1 and two types for REF2. The insulation has been distinguished by material types and thickness.

For both reference buildings, two windows variant types have been included in the analysis. These consist of a metal frame with thermal break and wood, having a double glazing with shutters. As regards technical systems, the analysis includes the substitution of the old generation and emission systems, considering different variants of heat pumps and other emission systems (Table 5). 
Table 5. Variants of technical systems of reference buildings.

\begin{tabular}{|c|c|c|c|c|c|c|c|c|c|c|}
\hline \multicolumn{11}{|c|}{ Generation } \\
\hline \multirow{2}{*}{ ID } & \multirow{2}{*}{ Description } & \multirow{2}{*}{$\begin{array}{l}\text { Energy } \\
\text { Vector }\end{array}$} & \multirow{2}{*}{$\begin{array}{c}\text { Heat } \\
\text { Source }\end{array}$} & \multirow{2}{*}{$\begin{array}{l}\text { Unit } \\
\text { Number }\end{array}$} & \multirow{2}{*}{$\begin{array}{c}P_{h} \\
\mathrm{~kW}\end{array}$} & \multirow{2}{*}{$\begin{array}{c}P_{c} \\
\mathrm{~kW}\end{array}$} & \multirow{2}{*}{$\begin{array}{c}T_{h, \text { out }} \\
{ }^{\circ} \mathrm{C}\end{array}$} & \multirow{2}{*}{$\frac{T_{w, \text { out }}}{{ }^{\circ} \mathrm{C}}$} & \multirow{2}{*}{$\eta-C O P$} & \multirow{2}{*}{ SEER } \\
\hline & & & & & & & & & & \\
\hline REF1_GEN01 & $\begin{array}{l}\text { centralized } \\
\text { heat pump }\end{array}$ & electricity & air & 1 & 13.8 & 11.7 & 45 & 45 & 3.19 & 4.81 \\
\hline REF1_GEN02 & $\begin{array}{l}\text { centralized } \\
\text { heat pump }\end{array}$ & electricity & ground & 1 & 14.2 & 16.5 & 45 & 45 & 4.51 & 3.52 \\
\hline REF1_GEN03 & $\begin{array}{l}\text { centralized } \\
\text { heat pump }\end{array}$ & electricity & air & 1 & 14.3 & 13 & 38 & 35 & 4.07 & 6.56 \\
\hline REF2_GEN01 & heat pump & electicity & air & 1 & 40.9 & 35.3 & 55 & 50 & 3.40 & 3.53 \\
\hline REF2_GEN02 & heat pump & electicity & air & 1 & 71.2 & 85.5 & 55 & 50 & 4.10 & 3.69 \\
\hline REF2_GEN03 & heat pump & electicity & ground & 1 & 26.2 & 39.9 & 55 & 50 & 4.45 & 6.15 \\
\hline REF2_GEN04 & heat pump & electicity & ground & 1 & 73 & 108 & 55 & 50 & 4.41 & 5.39 \\
\hline REF2_GEN05 & heat pump & electicity & air & 1 & 29.1 & 32.8 & 35 & 50 & 4.11 & 3.98 \\
\hline REF2_GEN06 & heat pump & electicity & air & 1 & 71.2 & 85.5 & 35 & 50 & 4.12 & 3.87 \\
\hline REF2_GEN07 & heat pump & electicity & ground & 1 & 26.2 & 39.9 & 35 & 50 & 4.45 & 6.15 \\
\hline REF2_GEN08 & heat pump & electicity & ground & 1 & 73 & 108 & 35 & 50 & 4.41 & 5.39 \\
\hline \multicolumn{11}{|c|}{ Emission } \\
\hline \multirow{2}{*}{ ID } & \multirow{2}{*}{ Description } & \multicolumn{2}{|c|}{ Unit Number } & \multicolumn{2}{|l|}{$\eta_{\mathrm{e}}$} & \multicolumn{2}{|c|}{$\eta_{d}$} & \multicolumn{2}{|c|}{$\eta_{\mathrm{r}}$} & $\eta_{\mathrm{s}}$ \\
\hline & & \multicolumn{2}{|c|}{ n. - $\mathrm{m}^{2}$} & \multicolumn{2}{|l|}{$\%$} & \multicolumn{2}{|c|}{$\%$} & & & $\%$ \\
\hline REF1_EM01 & fancoils & 1 & & 98 & & & & & & 100 \\
\hline REF1_EM02 & AHU & 1 & & 96 & & & & & & 100 \\
\hline REF1_EM03 & $\begin{array}{c}\text { fancoil + radiant } \\
\text { panels }\end{array}$ & 10 & 200 & 99 & & & & & & 100 \\
\hline REF2_EM01 & $\mathrm{AHU}$ & 1 & & 94 & & & & & & 100 \\
\hline REF2_EM02 & fancoils & 2 & & 96 & & & 5 & & & 100 \\
\hline REF2_EM03 & $\begin{array}{c}\text { radiant } \\
\text { panels }+ \text { fancoils }\end{array}$ & 27 & 500 & 98 & & & 5 & & & 100 \\
\hline & & & & Ventilation & & & & & & \\
\hline ID & Description & Unit N & umber & $q_{v, e}$ & $q_{v, \text { tot }}$ & $\eta_{\theta_{w, d}}$ & $\eta_{\theta_{s, d}}$ & $S F P_{d}$ & $V_{N}$ & $t_{B}$ \\
\hline & & & & $\mathrm{m}^{3} / \mathrm{h}$ & $\mathrm{m}^{3} / \mathrm{h}$ & $\%$ & $\%$ & $\mathrm{Wh} / \mathrm{m}^{3}$ & $\mathrm{~m}^{3}$ & h/day \\
\hline REF1_VENT01 & CMV & 1 & & 1900 & 2000 & $57 \%$ & 50 & 0.34 & 1728 & 8 \\
\hline REF1_VENT02 & $\begin{array}{l}\text { static heat } \\
\text { recovery }\end{array}$ & 1 & & 1900 & 4500 & $83 \%$ & 69.9 & 0.45 & 1728 & 6 \\
\hline REF2_VENT01 & $\begin{array}{l}\text { static heat } \\
\text { recovery }\end{array}$ & 1 & & 5580 & 9800 & $55 \%$ & 0.53 & 0.67 & 3244 & 8 \\
\hline REF2_VENT02 & CMV & 2 & & 2790 & 3000 & $50 \%$ & 0.5 & 0.54 & 3244 & 8 \\
\hline & & & & estic Hot V & ater & & & & & \\
\hline ID & Description & $\begin{array}{c}\text { Unit } \\
\text { Number }\end{array}$ & $\eta_{e, w}$ & $\eta_{d, w}$ & & & $V$ & $t_{i}$ & $T_{s t}$ & $h_{s t}$ \\
\hline & & $n$. & $\%$ & $\%$ & & & $\mathbf{L}$ & $\mathrm{cm}$ & ${ }^{\circ} \mathrm{C}$ & h \\
\hline REF1_DHW01 & $\begin{array}{l}\text { combined / solar } \\
\text { collectors }\end{array}$ & 1 & 95 & 96 & & & 500 & 7 & 50 & 24 \\
\hline REF2_DHW01 & $\begin{array}{l}\text { combined/solar } \\
\text { collectors }\end{array}$ & 1 & 95 & 96 & & & 1850 & 5 & 50 & 24 \\
\hline & & & Renew & ble Energy & Source & & & & & \\
\hline ID & Descrintion & $A_{N}$ & $N_{o}$ & $P_{p e a k, p}$ & & & $e a k$ & $f_{s}$ & $f_{N}$ & $\eta_{k}$ \\
\hline ID & Description & $\mathrm{m}^{2}$ & - & $W$ & & & $W$ & degrees & degrees & $\%$ \\
\hline REF1_SC01 & $\begin{array}{l}\text { solar collector } \\
\text { panels }\end{array}$ & 2 & 10 & - & & & - & 0 & 45 & 55 \\
\hline REF1_PV01 & $\begin{array}{l}\text { photovoltaic } \\
\text { panels }\end{array}$ & 1.5 & 12 & 250 & & & 00 & 0 & 45 & 17 \\
\hline REF1_PV02 & $\begin{array}{l}\text { photovoltaic } \\
\text { panels }\end{array}$ & 1.5 & 18 & 250 & & & 50 & 0 & 45 & 17 \\
\hline REF2_SC01 & $\begin{array}{l}\text { solar collector } \\
\text { panels }\end{array}$ & 2 & 17 & - & & & - & 0 & 45 & 55 \\
\hline REF2_PV01 & $\begin{array}{l}\text { photovoltaic } \\
\text { panels }\end{array}$ & 1.5 & 60 & 250 & & & .00 & 0 & 45 & 17 \\
\hline REF2_PV02 & $\begin{array}{l}\text { photovoltaic } \\
\text { panels }\end{array}$ & 1.5 & 68 & 250 & & & .00 & 0 & 45 & 17 \\
\hline
\end{tabular}


For REF1, the largest number of variants relates to the envelope, in particular for insulation. This approach was adopted in order to investigate the effect of different materials and thickness of the insulation as well as the effect of different efficiencies of the generation system. For REF2, eight generation systems have been considered to identify the best configuration taking into account the performance variability of the thermal energy production.

A controlled mechanical ventilation has been considered in the analysis to guarantee proper indoor air quality and comfort, a fundamental aspect for school buildings. In particular, the ventilation variants include for each reference building: CMV with static heat recovery combined with fancoils and/or radiant panels with fancoils for dehumidification, and a static heat recovery in the air handle unit to control the indoor conditioned air. RES systems have been included in order to reduce energy consumption and $\mathrm{CO}_{2}$ emissions. In particular, for both buildings, solar collector panels and photovoltaic systems have been included in order to ensure 35\% coverage of the total energy demand.

\subsection{Energy Performance and Global Costs Assessment}

After the definition of the reference buildings and the selection of energy efficiency retrofit measures, primary energy demand and global costs have been derived for all variants using the software ProCasaClima2015 v.2.0 (KlimaHaus, Agentur für Energie Südtirol, Bozen, Italy), based on an Excel workbook. It is useful to calculate the building performance from an energetic, environmental and economic point of view, showing a clear sensitivity of the climate data compared to the most popular dynamic software [44]. Heating, cooling, ventilation, domestic hot water, lighting and auxiliary demands have been estimated in accordance with the Standard UNI TS 11300 (part 1 and 2) [12]. The characteristics of energy production, distribution, emission and control, as well as the energy carrier, have been inserted to derive final uses energy consumption. UNI EN ISO 13370 [45] is incorporated in the software to calculate the heat exchange with the ground, as well as the global efficiency of building plants and $\mathrm{CO}_{2}$ emissions. Furthermore, it is possible to evaluate global costs in compliance with UNI EN 15459 [11]. The calculation of the net energy requirements in terms of primary energy consumption is divided into the following phases:

(1) Calculation of the net thermal energy needs to meet the users' requirements: in winter the energy demand is calculated as the energy loss through the envelope and ventilation minus the internal gains and natural energy earnings (passive solar heating, passive cooling, natural ventilation, etc.);

(2) Subtraction from the first point of the thermal energy obtained from renewable sources and used in situ (for example the energy obtained from solar collectors);

(3) Calculation of energy consumption, in terms of energy carriers (electricity, fuel) for each use (heating and cooling of environments, hot water, lighting, ventilation), taking into account the characteristics (seasonal efficiency) of production, distribution, emission and control systems;

(4) Subtraction of energy produced from renewable sources and used in situ from electricity consumption (for example the energy produced by photovoltaic panels);

(5) Calculation of energy supplied for each energy carrier as sum of energy consumption (not covered by the energy from renewable sources);

(6) Calculation of primary energy associated with supplied energy, using national conversion factors;

(7) Calculation of primary energy associated with energy exported to the market (for example the energy generated from renewable sources or co-generators in situ);

(8) Calculation of primary energy as the difference between the two previous amounts (6) and (7).

For the calculation of energy consumption for heating, cooling environments, and the production of hot water it is necessary to consider the seasonal efficiency of the systems and perform a dynamic simulation accordingly.

The global cost has been estimated in terms of net present value for each combination. The regulation suggests to carry out both a macroeconomic and a financial calculation. In the second case, taxes, VAT, charges and subsidies are included. 
The global cost calculation also considers initial investment cost $C_{I}$, an annual cost for each component or system, and a final value derived by a linear depreciation of the initial investment until the end of the calculation period, $\tau$.

The final replacement cost (that includes the price for products, $R_{P}$ ), the discount rate at the end of the calculation period $\left(R_{d}\right)$, and the real interest rate $\left(R_{R}\right.$, that depends on the market interest rate $\mathrm{R}$ and on the inflation rate $R_{I}$ ) have been included in the evaluation of global costs with calculation a period of 20 years. The following formula is used for the global costs calculation:

$$
C_{G}(\tau)=C_{I}+\sum_{j}\left[\sum_{i=1}^{\tau}\left(C_{a, i}(i) * R_{d}(i)\right)-V_{f, \tau}(j)\right]
$$

where:

- $\tau$ is the calculation period;

- $C_{G}(\tau)$ is the global cost (referred to starting year $\tau_{0}$ ) in the calculation period $\tau$;

- $C_{I}$ is the initial cost of the measure or set of measures $j$;

- $C_{a, i}(i)$ represents the annual cost, during year $i$, for measure or set of measures;

- $V_{f, \tau}(j)$ represents the residual value of measure or set of measures $j$ at the end of the calculation period;

- $\quad R_{d}(i)$ is the discount factor for year $i$.

The assessment is dynamic, and takes into account the annual changes in the discount rate and annual variations in the growth rate of prices for any one of the annual costs considered (energy, operating, periodic, replacement, maintenance and additional costs). The final value of a component $\left(V_{f, \tau}(j)\right)$ is determined by straight-line depreciation of the initial investment until the end of the calculation period and referred to the beginning of the calculation period. If the calculation period $\tau$ exceeds the lifespan of a component $j\left(\tau_{n}(j)\right)$, it is considered the last replacement cost in the linear depreciation. The residual value $\left(V_{f, \tau}(j)\right)$ is assessed using the following formula:

$$
V_{f, \tau}(j)=V_{0}(j) *\left(1+R_{p} / 100\right)^{n_{\tau}(j) * \tau_{n}(j)} * \frac{n_{\tau}(j)+1 * \tau_{n}(j)-\tau}{\tau_{n}(j)} * R_{d}(\tau)
$$

where:

- $\quad V_{f, \tau}(j)=V_{0}(j) *\left(1+R_{p} / 100\right)^{n_{\tau}(j) * \tau_{n}(j)}$ is the last replacement cost taking into account the growth rate of the product price $R_{p}$;

- $n_{\tau}(j)$ represents the total number of element $j$ replacement at the end of the period of calculation;

- $\quad \frac{n_{\tau}(j)+1 * \tau_{n}(j)-\tau}{\tau_{n}(j)}$ represents the linear depreciation of the last replacement cost (calculated as the remaining lifetime of the component $j$ last replacement at the end of the calculation period, divided by the lifespan of component $j$ );

- $R_{d}(\tau)$ represents the discount rate at the end of the calculation period:

$$
R_{d}(\tau)=\left(\frac{1}{1+R_{R} / 100}\right)^{\tau}
$$

$R_{R}$ represents the real interest rate and it depends on the market rate of interest $R$ and the annual inflation rate $\left(R_{i}\right)$ as shown in the following formula:

$$
R_{R}=\frac{R-R_{i}}{1+R_{i} / 100}
$$

- $V_{0}(j)$ is the initial investment cost;

- $\tau_{n}(j)$ is the component $j$ lifespan. 
A sensitivity analysis has been also carried out. This is an ex ante evaluation of the results that depends upon key parameters whose future trends can affect final results.

A sensitivity analysis is suggested in relation to different national energy prices both for the financial and for the microeconomic analysis. The discount rate has to be included in the calculation of cost-optimal levels.

Although the future trend of technology prices has no impact on the initial investment costs, evaluated at the beginning of the calculation period and referring to the prices drafted by the Puglia Region and a market survey, it represents a fundamental factor for the review of the calculations of cost optimal levels.

\section{Results and Discussion}

The first reference building (REF1, the kindergarten school in Sanarica) presents 288 combinations that show a huge variation of primary energy demand compared to the reference scenario. This has a primary energy consumption of $613 \mathrm{kWh} / \mathrm{m}^{2} \mathrm{y}$ and $179 \mathrm{kgCO}_{2} / \mathrm{m}^{2} \mathrm{y}$ greenhouse gas emissions, falling within national energy class F. Figure 2 shows the cost-optimal level, both for the financial and the macroeconomic analysis, of the most performing group of combinations which have PV02 as photovoltaic system variant.
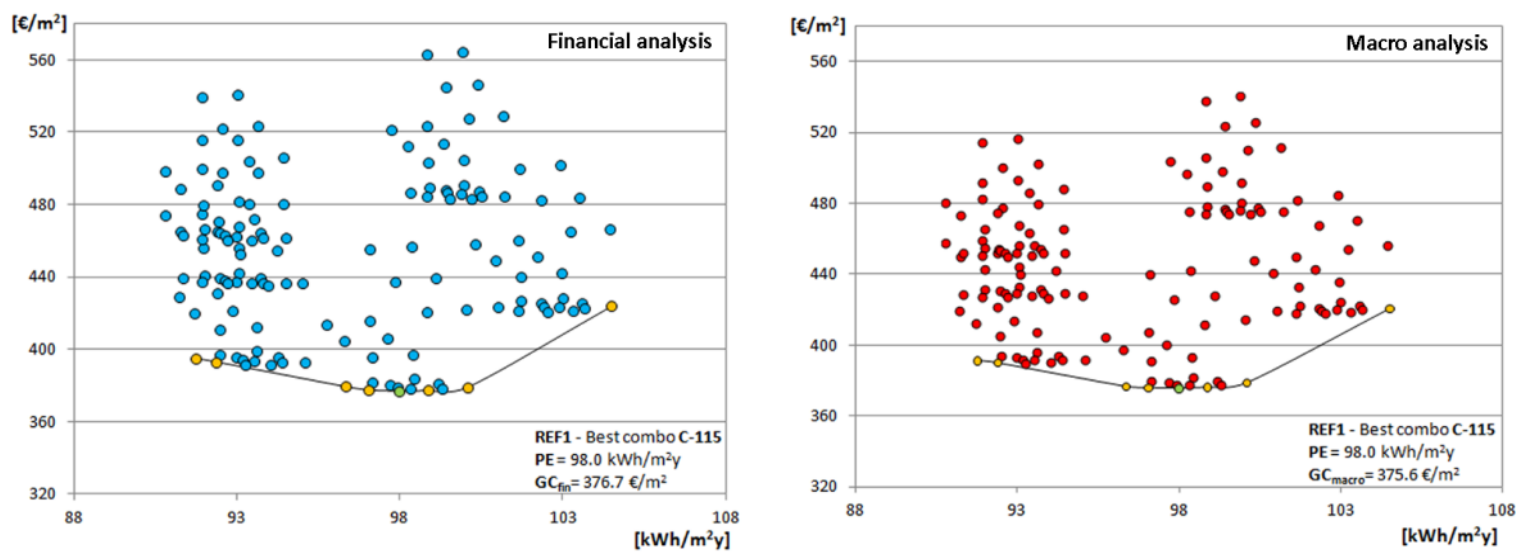

Figure 2. Cost-optimal level of reference building 1 (REF1) for financial and macroeconomic analysis.

The best combination falls within energy class B with a primary energy consumption of $98.0 \mathrm{kWh} / \mathrm{m}^{2} \mathrm{y}$ and $32 \mathrm{kgCO} / \mathrm{m}^{2} \mathrm{y}$ greenhouse gas emission, having a financial and macroeconomic global cost of $376.7 € / \mathrm{m}^{2}$ and $375.6 € / \mathrm{m}^{2}$, respectively. This solution has been obtained through the combination of the following measures: hemp fibers panels with $6 \mathrm{~cm}$ thickness (REF1_INS07, average transmittance value of external walls: $0.33 \mathrm{~W} / \mathrm{m}^{2} \mathrm{~K}$ ), wood frame for windows (REF1_WI02, $U_{\text {frame }}=1.3 \mathrm{~W} / \mathrm{m}^{2} \mathrm{~K}$ ), centralized heat pump with air heat source (REF1_GEN01), fancoils for emission (REF1_EM01) with controlled mechanical ventilation (REF1_VENT01), and photovoltaic system (REF1_PV02) consisting of 18 panels with $4.5 \mathrm{~kW}$ peak power and $17 \%$ efficiency. The best performing solution shows $84 \%$ reduction of primary energy consumption and $82 \%$ reduction of $\mathrm{CO}_{2}$ emissions compared to the reference building.

Figure 3 shows the comparison between the output values of monthly energy demand for heating, cooling, domestic hot water, lighting and auxiliary energy of the reference building (REF1) and the best combination (C-115). 

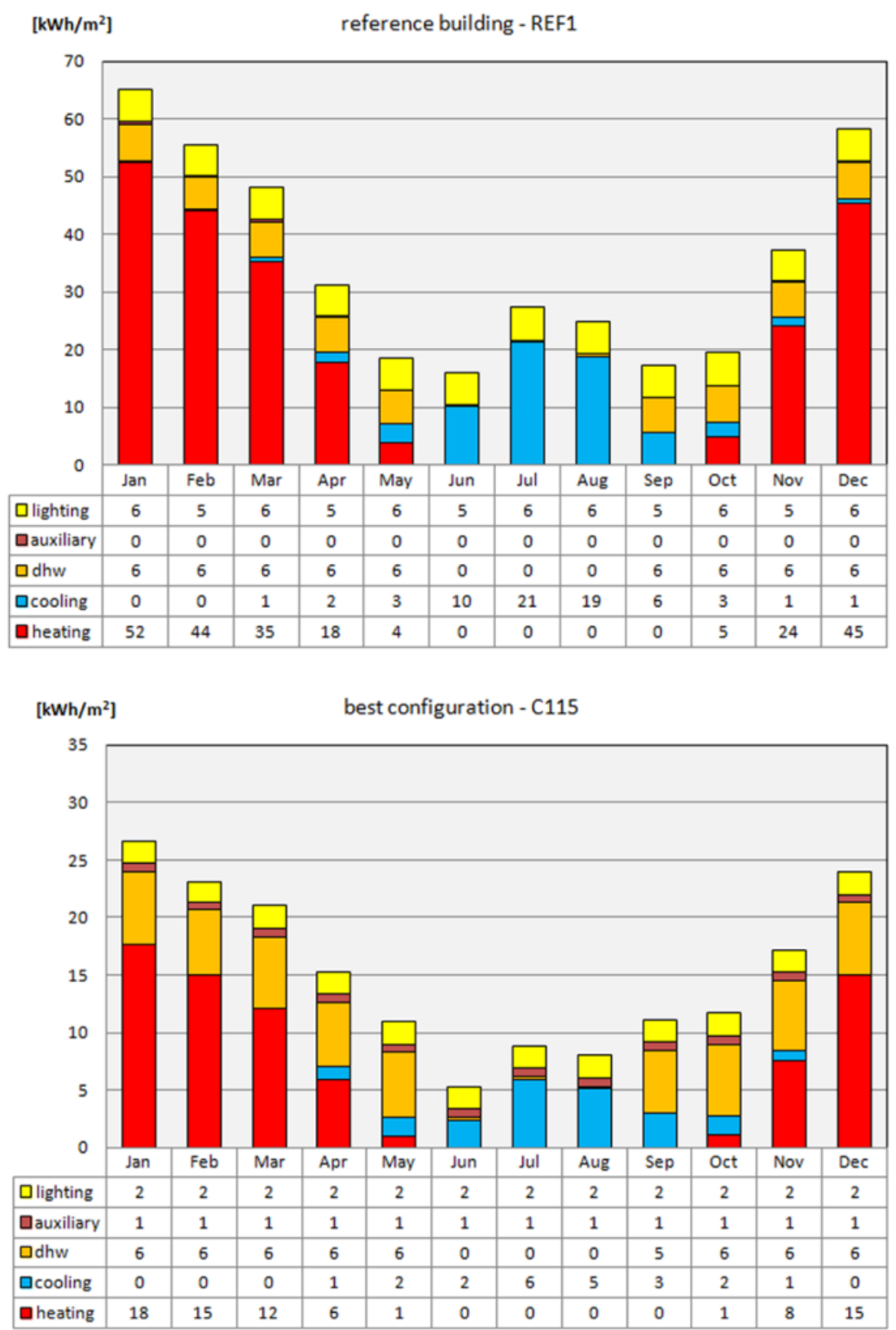

Figure 3. Energy demand of reference building 1 (REF1) and the best configuration (REF1—C-115).

It is possible to note that the variants included in this combination reduce the heating demand from the highest value of 52 to $18 \mathrm{kWh} / \mathrm{m}^{2}$ with a reduction of about $65 \%$ compared to the reference case. In the hottest month, the cooling energy demand is not as high as the heating energy demand in the coldest month. However, it decreases significantly, passing from 21 to $6 \mathrm{kWh} / \mathrm{m}^{2}$, providing a reduction of about $71 \%$. Although both energy demands are reduced, auxiliary energy demand increases by about $10 \%$. Furthermore, the lamps selected for lighting give a lower consumption compared to the reference building. In particular, this energy demand passes from 6 to $2 \mathrm{kWh} / \mathrm{m}^{2}$.

Ninety-six combinations have been performed in the analysis for REF 2 (in Squinzano), pointing out the variation of primary energy consumption in comparison with the reference scenario.

In accordance with the national energy performance classification, the nursery belongs to class $\mathrm{G}$, with a consumption of primary energy of $418 \mathrm{kWh} / \mathrm{m}^{2} \mathrm{y}$ and $113 \mathrm{CO}_{2} / \mathrm{m}^{2} \mathrm{y}$. Figure 4 shows the global costs and the primary energy consumption for the financial and microeconomic analyses of all combinations. 

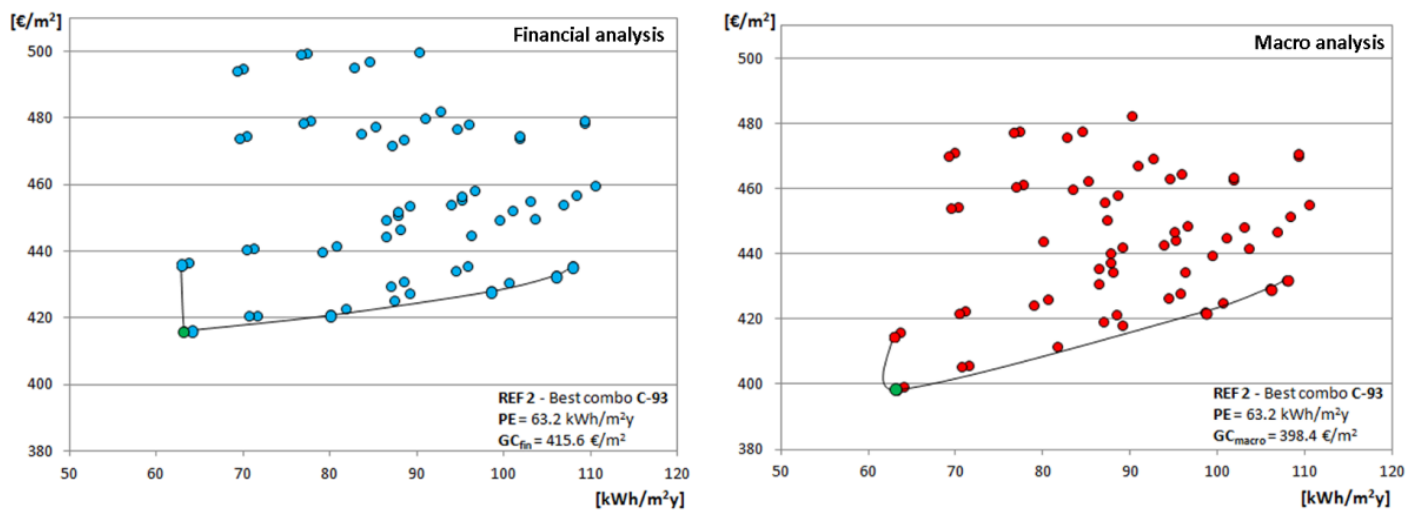

Figure 4. Cost-optimal level of reference building 2 (REF2) obtained from a financial and macroeconomic analysis.
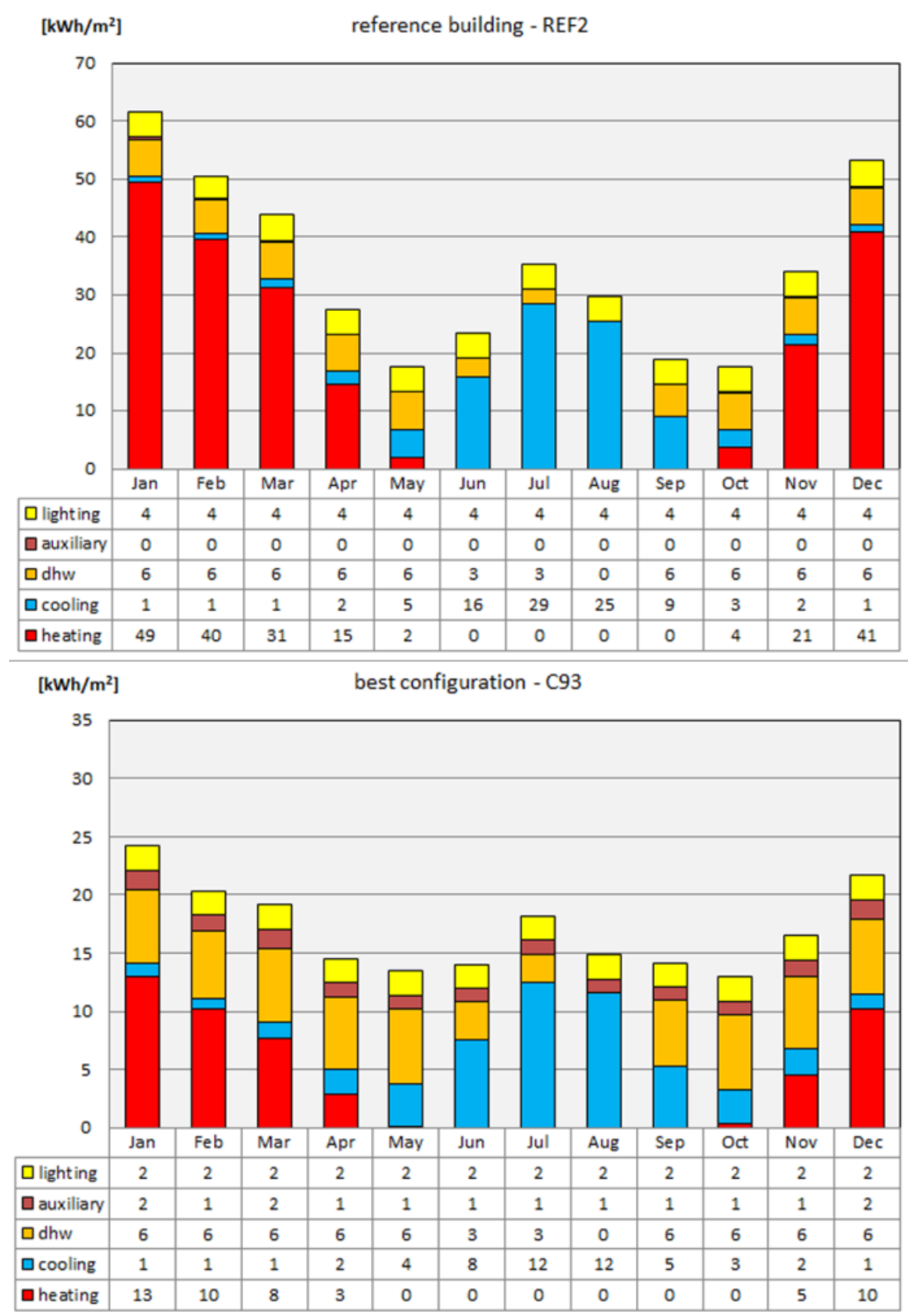

Figure 5. Energy demand of reference building 2 (REF2) and the best configuration (REF2-C-93). 
The best performing solution, found at the minimum point of the cost optimal curve in both analyses is the combination C93 $\left(P E=63.2 \mathrm{kWh} / \mathrm{m}^{2} \mathrm{y}, G C_{\text {fin }}=416.6 € / \mathrm{m}^{2}, G C_{\text {macro }}=398.4 € / \mathrm{m}^{2}\right)$. This combination has an external envelope of hemp fiber panels (REF2_INS02, average transmittance value of external walls equal to $0.33 \mathrm{~W} / \mathrm{m}^{2} \mathrm{~K}$ ), windows with stratified double insulated glazing, solar coating and wood frame (REF2_WI02, $U_{\text {frame }}=1.3 \mathrm{~W} / \mathrm{m}^{2} \mathrm{~K}$ ), geothermal heat pump (REF2_GEN03), emission system with fancoils and radiant panels (REF2_EM03), controlled mechanical ventilation (REF2_VENT02) and 68 photovoltaic modules (REF2_PV02). The lowest point of the curve gives savings of primary energy consumption and $\mathrm{CO}_{2}$ emissions equal to $85 \%$ and $82 \%$, respectively.

Figure 5 shows the comparison between the values of monthly energy demand for heating, cooling domestic hot water, lighting and auxiliary energy, of the reference building and the best performing solution (C93).

In the coldest month (January), heating demand decreases from 49 to $13 \mathrm{kWh} / \mathrm{m}^{2}$, with a reduction of $73 \%$ compared to the reference building. In the hottest month (July) the cooling demand decreases from 29 to $12 \mathrm{kWh} / \mathrm{m}^{2}$, showing a $58 \%$ reduction from the reference scenario. The monthly lighting demand increases by $50 \%$ compared to base case, as well as the auxiliary demand that increases to $2 \mathrm{kWh} / \mathrm{m}^{2}$ in the coldest months (December and January) and to $1 \mathrm{kWh} / \mathrm{m}^{2}$ in the remaining months. Figures 6 and 7 show the sensitivity analysis of the best combinations of REF1 and REF2 in terms of macroeconomic and financial analyses.

They have been obtained considering real interest rates of: $2.52 \%, 3 \%, 4 \%$ for the financial analysis, and of $2.52 \%, 4 \%, 5 \%$ for the macroeconomic analysis. It is assumed that the rate of increase of the electricity price goes from $2.4 \%$ to $2.8 \%$ in both analyses.

All possible combinations of rates have been taken into account in order to have a more complete description of cost trends.
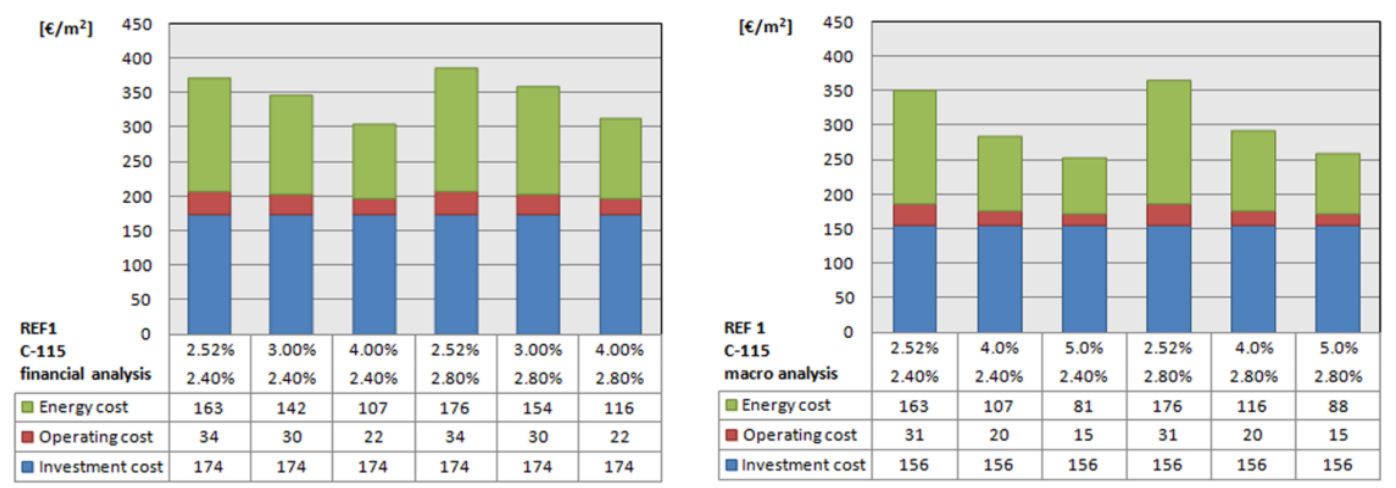

Figure 6. Financial and macroeconomic sensitivity analysis of the best combination for REF1.
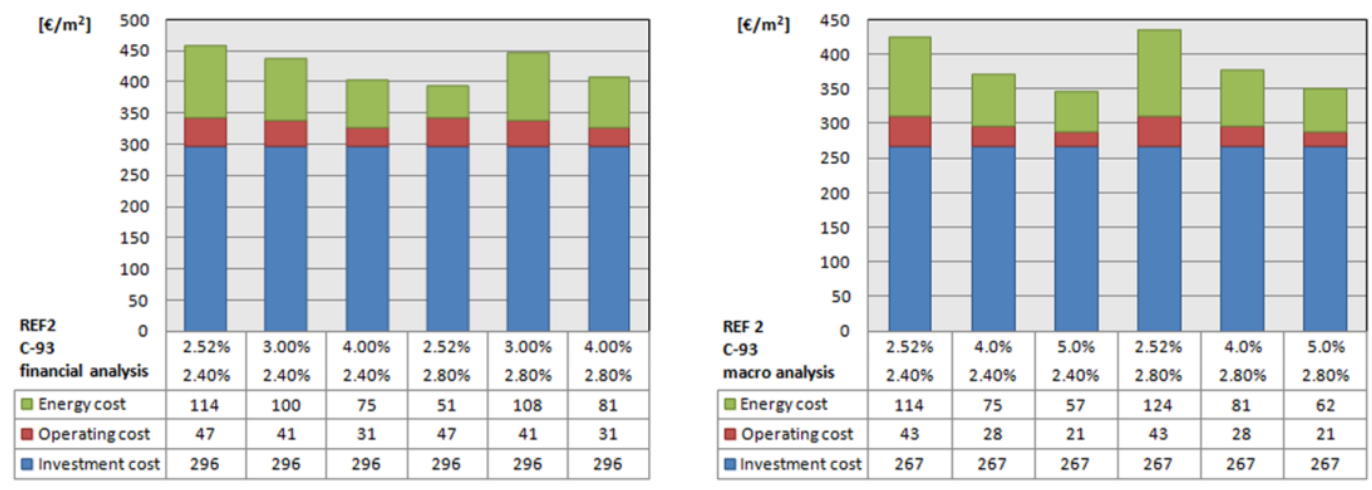

Figure 7. Financial and macroeconomic sensitivity analysis of the best combination for REF2.

Tables 6 and 7 show different groups of solutions obtained by grouping the combinations according to the related primary energy consumption reduction. 
Table 6. Range of primary energy consumptions and global costs of combinations for REF1.

\begin{tabular}{|c|c|c|c|c|c|c|c|c|}
\hline \multirow{2}{*}{ Group } & \multirow{2}{*}{ No Combo } & PE Range & $\mathrm{CO}_{2}$ Range & PE Red. \% & $\mathrm{CO}_{2}$ Red. $\%$ & $P E_{\text {avarage }}$ & $G C_{\text {avarage,fin }}$ & \multirow{2}{*}{ Technical System Combinations } \\
\hline & & $\mathrm{kWh} / \mathrm{m}^{2} \mathrm{y}$ & $\mathrm{kgCO}_{2} / \mathrm{m}^{2} \mathrm{y}$ & $\%$ & $\%$ & $\mathrm{kWh} / \mathrm{m}^{2} \mathrm{y}$ & $\epsilon / m^{2}$ & \\
\hline REF1_group 1 & 9 & $119.56-121.12$ & $39-40$ & $80 \%$ & $78 \%$ & 120.17 & 458.39 & GEN01-EM02-VENT01-PV01 \\
\hline REF1_group 2 & 60 & $113.65-119.51$ & 37-39 & $81 \%$ & $78 \%-79 \%$ & 116.28 & 471.60 & $\begin{array}{l}\text { GEN01-EM01-VENT01-PV01 } \\
\text { GEN01-EM02-VENT02-PV01 } \\
\text { GEN02-EM02-VENT02-PV01 }\end{array}$ \\
\hline REF1_group 3 & 75 & $107.39-112.98$ & $35-37$ & $82 \%$ & $79 \%-80 \%$ & 109.60 & 467.64 & $\begin{array}{l}\text { GEN01-EM01-VENT01-PV01 } \\
\text { GEN02-EM01-VENT01-PV01 } \\
\text { GEN02-EM02-VENT02-PV01 } \\
\text { GEN03-EM03-VENT01-PV01 }\end{array}$ \\
\hline REF1_group 4 & 22 & $101.20-104.51$ & 33-34 & $83 \%$ & $81 \%-82 \%$ & 102.68 & 447.94 & $\begin{array}{l}\text { GEN01-EM02-VENT02-PV02 } \\
\text { GEN02-EM02-VENT02-PV02 }\end{array}$ \\
\hline REF1_group 5 & 51 & $95.08-101.14$ & $31-33$ & $84 \%$ & $82 \%-83 \%$ & 98.76 & 452.41 & $\begin{array}{l}\text { GEN01-EM01-VENT01-PV02 } \\
\text { GEN01-EM02-VENT02-PV02 } \\
\text { GEN02-EM02-VENT02-PV02 } \\
\text { GEN03-EM03-VENT01-PV02 }\end{array}$ \\
\hline REF1_group 6 & 71 & $90.78-95.01$ & $30-31$ & $85 \%$ & $83 \%$ & 92.83 & 454.94 & $\begin{array}{l}\text { GEN02-EM01-VENT01-PV02 } \\
\text { GEN02-EM03-VENT01-PV02 } \\
\text { GEN03-EM03-VENT01-PV02 }\end{array}$ \\
\hline
\end{tabular}

Table 7. Range of primary energy consumptions and global costs of combinations for REF2.

\begin{tabular}{|c|c|c|c|c|c|c|c|c|}
\hline \multirow{2}{*}{ Group } & \multirow{2}{*}{ No Combo } & \multirow{2}{*}{$\begin{array}{l}\text { PE Range } \\
\mathrm{kWh} / \mathrm{m}^{2} \mathrm{y}\end{array}$} & \multirow{2}{*}{$\frac{\mathrm{CO}_{2} \text { Range }}{\mathrm{kgCO}_{2} / \mathrm{m}^{2} \mathrm{y}}$} & \multirow{2}{*}{$\begin{array}{c}\text { PE Red. } \% \\
\%\end{array}$} & \multirow{2}{*}{$\begin{array}{c}\mathrm{CO}_{2} \text { Red. } \% \\
\% \\
\end{array}$} & \multirow{2}{*}{$\begin{array}{c}P E_{\text {avarage }} \\
\mathrm{kWh} / \mathrm{m}^{2} \mathrm{y}\end{array}$} & \multirow{2}{*}{$\frac{G C_{\text {avarage,fin }}}{€ / \mathrm{m}^{2}}$} & \multirow{2}{*}{ Technical System Combinations } \\
\hline & & & & & & & & \\
\hline REF_2 group 1 & 4 & $207-209$ & $68-69$ & $50 \%$ & $39 \%-40 \%$ & 208.47 & 594.85 & $\begin{array}{l}\text { GEN01-EM01-VENT01-PV01 } \\
\text { GEN02-EM01-VENT01-PV01 }\end{array}$ \\
\hline REF_2 group 2 & 2 & 203-204 & 67 & $51 \%$ & $41 \%$ & 203.54 & 577.01 & $\begin{array}{l}\text { GEN01-EM01-VENT01-PV01 } \\
\text { GEN02-EM01-VENT01-PV01 }\end{array}$ \\
\hline REF_2 group 3 & 5 & $200-202$ & $66-67$ & $52 \%$ & $41 \%-42 \%$ & 201.00 & 592.41 & $\begin{array}{l}\text { GEN02-EM01-VENT01-PV01 } \\
\text { GEN02-EM01-VENT01-PV02 } \\
\text { GEN01-EM01-VENT01-PV02 }\end{array}$ \\
\hline REF_2 group 4 & 3 & 196-197 & 65 & $53 \%$ & $42 \%$ & 196.30 & 574.26 & $\begin{array}{l}\text { GEN01-EM01-VENT01-PV01 } \\
\text { GEN01-EM01-VENT01-PV02 } \\
\text { GEN02-EM01-VENT01-PV01 }\end{array}$ \\
\hline REF_2 group 5 & 2 & $192-193$ & $63-64$ & $54 \%$ & $43 \%-44 \%$ & 192.88 & 643.15 & $\begin{array}{l}\text { GEN04-EM01-VENT01-PV01 } \\
\text { GEN02-EM01-VENT01-PV02 }\end{array}$ \\
\hline
\end{tabular}


Table 7. Cont.

\begin{tabular}{|c|c|c|c|c|c|c|c|c|}
\hline \multirow{2}{*}{ Group } & \multirow{2}{*}{ No Combo } & \multirow{2}{*}{$\begin{array}{l}\text { PE Range } \\
\mathrm{kWh} / \mathrm{m}^{2} \mathrm{y}\end{array}$} & \multirow{2}{*}{$\begin{array}{l}\mathrm{CO}_{2} \text { Range } \\
\mathrm{kgCO}_{2} / \mathrm{m}^{2} \mathrm{y}\end{array}$} & \multirow{2}{*}{$\begin{array}{c}\text { PE Red. } \% \\
\% \\
\end{array}$} & \multirow{2}{*}{$\begin{array}{c}\mathrm{CO}_{2} \text { Red. } \% \\
\% \\
\end{array}$} & \multirow{2}{*}{$\begin{array}{l}P E_{\text {avarage }} \\
\mathrm{kWh} / \mathrm{m}^{2} \mathrm{y}\end{array}$} & \multirow{2}{*}{$\frac{G C_{\text {avarage,fin }}}{€ / \mathrm{m}^{2}}$} & \multirow{2}{*}{ Technical System Combinations } \\
\hline & & & & & & & & \\
\hline REF_2 group 6 & 4 & 186-189 & $61-63$ & $55 \%$ & $44 \%-46 \%$ & 188.70 & 631.11 & $\begin{array}{l}\text { GEN03-EM01-VENT01-PV01 } \\
\text { GEN04-EM01-VENT01-PV01 } \\
\text { GEN01-EM01-VENT01-PV02 }\end{array}$ \\
\hline REF_2 group 7 & 6 & 181-186 & $60-61$ & $56 \%$ & $46 \%-47 \%$ & 183.63 & 629.63 & $\begin{array}{l}\text { GEN04-EM01-VENT01-PV01 } \\
\text { GEN04-EM01-VENT01-PV02 } \\
\text { GEN03-EM01-VENT01-PV01 } \\
\text { GEN03-EM01-VENT01-PV02 }\end{array}$ \\
\hline REF_2 group 8 & 3 & 178-179 & 59 & $57 \%$ & $48 \%$ & 178.72 & 606.60 & $\begin{array}{l}\text { GEN03-EM01-VENT01-PV01 } \\
\text { GEN03-EM01-VENT01-PV02 } \\
\text { GEN04-EM01-VENT01-PV02 }\end{array}$ \\
\hline REF_2 group 9 & 2 & $176-177$ & 58 & $58 \%$ & $49 \%$ & 175.89 & 621.05 & $\begin{array}{l}\text { GEN04-EM01-VENT01-PV02 } \\
\text { GEN03-EM01-VENT01-PV02 }\end{array}$ \\
\hline REF_2 group 10 & 1 & 172 & 57 & $59 \%$ & $50 \%$ & 171.82 & 565.09 & GEN03-EM01-VENT01-PV02 \\
\hline REF_2 group 11 & 7 & 108-110 & 29-36 & $74 \%$ & $68 \%-79 \%$ & 105.56 & 458.73 & $\begin{array}{l}\text { GEN01-EM02-VENT02-PV01 } \\
\text { GEN02-EM02-VENT02-PV01 }\end{array}$ \\
\hline REF_2 group 12 & 3 & 103-105 & 34-35 & $75 \%$ & $69 \%-70 \%$ & 104.07 & 445.81 & $\begin{array}{l}\text { GEN02-EM02-VENT02-PV02 } \\
\text { GEN01-EM02-VENT02-PV01 }\end{array}$ \\
\hline REF_2 group 13 & 6 & $97-102$ & $32-33$ & $76 \%$ & $71 \%-72 \%$ & 100.38 & 451.50 & $\begin{array}{l}\text { GEN01-EM02-VENT02-PV02 } \\
\text { GEN02-EM02-VENT02-PV02 }\end{array}$ \\
\hline REF_2 group 14 & 9 & $94-96$ & $26-31$ & $77 \%$ & $73 \%-81 \%$ & 93.65 & 453.68 & $\begin{array}{l}\text { GEN05-EM03-VENT02-PV01 } \\
\text { GEN06-EM03-VENT02-PV01 } \\
\text { GEN03-EM03-VENT02-PV02 } \\
\text { GEN01-EM02-VENT02-PV02 }\end{array}$ \\
\hline REF_2 group 15 & 4 & $90-94$ & 29-31 & $78 \%$ & $73 \%-74 \%$ & 91.73 & 479.21 & $\begin{array}{l}\text { GEN04-EM02-VENT02-PV01 } \\
\text { GEN05-EM03-VENT02-PV02 }\end{array}$ \\
\hline REF_2 group 16 & 11 & $86-89$ & $28-29$ & $79 \%$ & $74 \%-75 \%$ & 87.58 & 446.40 & $\begin{array}{l}\text { GEN03-EM02-VENT02-PV01 } \\
\text { GEN05-EM03-VENT02-PV02 } \\
\text { GEN06-EM03-VENT02-PV02 }\end{array}$ \\
\hline REF_2 group 17 & 5 & $82-85$ & $27-28$ & $80 \%$ & $75 \%-76 \%$ & 83.39 & 473.68 & $\begin{array}{l}\text { GEN04-EM02-VENT02-PV02 } \\
\text { GEN03-EM02-VENT02-PV02 }\end{array}$ \\
\hline REF_2 group 18 & 3 & $78-81$ & $25-26$ & $81 \%$ & $77 \%-78 \%$ & 78.79 & 446.68 & $\begin{array}{l}\text { GEN04-EM03-VENT02-PV01 } \\
\text { GEN03-EM02-VENT02-PV02 }\end{array}$ \\
\hline REF_2 group 19 & 3 & $76-77$ & 25 & $82 \%$ & $78 \%$ & 76.82 & 492.54 & GEN04-EM03-VENT02-PV01 \\
\hline REF_2 group 20 & $\begin{array}{l}8 \\
4\end{array}$ & $\begin{array}{l}70-71 \\
63-64\end{array}$ & $\begin{array}{l}22-23 \\
20-21\end{array}$ & $83 \%$ & $\begin{array}{l}80 \%-81 \% \\
81 \%-82 \%\end{array}$ & $\begin{array}{l}70.21 \\
63.41\end{array}$ & $\begin{array}{l}457.67 \\
42609\end{array}$ & $\begin{array}{l}\text { GEN03-EM03-VENT02-PV01 } \\
\text { GEN04-EM03-VENT02-PV02 } \\
\text { GENO3-FM03-VENTO2-PV0 }\end{array}$ \\
\hline REF_2 group 21 & 4 & 63-64 & $20-21$ & $85 \%$ & $81 \%-82 \%$ & 63.41 & 426.09 & GEN03-EM03-VENT02-PV02 \\
\hline
\end{tabular}


The results obtained from the analysis of the two reference buildings justify the different performance after the application of the methodology. The construction period of the building structures defines the reason why the values in reduction of primary energy consumption and the $\mathrm{CO}_{2}$ gas emissions are higher for the oldest building then for the other one. The initial status of the analyzed building affects the performance of the applied optimal solution. At the same time, the global cost, depending on the primary energy consumption is also reduced compared to a more recent building.

The results obtained for REF1 from a financial and a macroeconomic analysis show that considering thickness as a variant for insulation has a specific impact on cost-optimal levels. Although the envelope performance increases with the thickness, the investment costs and the global costs increase too. For this reason, it is useful to consider the material thermal properties together with the investment cost. The most performing variant of REF1 has been obtained through the thinnest hemp fiber panel considered. Furthermore, increasing the number of photovoltaic panels leads to a reduction of both primary energy consumption and global costs. This means that, despite investment cost increases, the energy demand decreases because of the highly efficient technical systems. A variation of the number of photovoltaic panels has been considered both for REF1 and REF2. The variant PV02 led REF2 to improve its cost optimal level, considering that the increasing number of photovoltaic panels has been included to optimize some combinations falling within national energy class $C$.

The best solution related to REF2 includes the geothermal heat pump (GEN03) with the best performance in heating and cooling, and the highest COP and SEER compared to the other heat pumps of the analysis. This indicates that the electrical power consumption is the lowest and, for this reason, the primary energy and the $\mathrm{CO}_{2}$ emission have the highest reduction ( $85 \%$ and $82 \%$, respectively), although the energy demand generated is the same for all combinations. The most performing solution has been obtained through the application of a high efficiency heat pump. Although the energy demand increases for auxiliary and domestic hot water, total monthly energy demand of the best solution is still lower than the energy requirement of the reference building. This means that the analysis has to carefully consider heating and cooling demands as the crucial parameters that can impact results in order to derive the highest primary energy savings in existing buildings.

It has to be pointed out that this study is based on cost assumptions that can change over time. As an example, fluctuations of energy prices as well as the relation with the discount rate influence global cost calculation and may slightly shift the cost-optimal point. Energy costs, inflation rate during the calculation period, and energy requirements can also vary and impact results.

\section{Conclusions}

While designing buildings as nZEBs seems to be feasible in many projects mainly in relation to new buildings or where RES are more available, rehabilitating the EU existing stock into efficient buildings is one of the main issues to be overcome in the near future [46]. Member States have to improve their national plans for a gradual transformation of existing buildings into nZEBs and provide their long-term strategies for mobilizing investment in renovation [47]. Despite their importance, school buildings are often characterized by high energy consumption and poor indoor air quality and thermal discomfort, without any air changing system.

This paper presents a set of solutions for two reference buildings: a kindergarten school and a nursery school located in the Mediterranean area (Southern Italy).

This paper shows how the cost-optimal methodology is useful in searching for the most appropriate retrofit measures for the renovation of existing public buildings. The requirements of primary energy consumption and RES have to take into account the resulting costs. It might be difficult to have the same level of minimum energy requirements in new and renovated buildings with equivalent timelines, because the cost-efficiency curve is different. The application of the methodology can practically drive the market demand towards a targeted energy retrofit. Life cycle assessment seems the most suitable approach in compliance with the EPBD requirements for existing buildings, which refer to the need for continuous policy and financial support. 
In school buildings, it is crucial to find the best balance between cost reduction and high comfort for a good student and user's performance. Improving comfort conditions and energy performance reducing operation costs appeared to be feasible in the presented case study.

The results obtained can be also used to highlight the differences between two kinds of building typologies, masonries and reinforced concrete structures not recently constructed. In order to obtain optimal conditions for old structures it is necessary to compare several solutions, obtaining global cost values slightly higher compared to more recent constructions. On the other hand, the renovation of historical buildings in Italy must be done considering the importance of such buildings for its cultural heritage. Moreover, the application of highly efficient solutions that reduce primary energy consumption and $\mathrm{CO}_{2}$ emissions is more significant in older buildings compared with the newest ones, since the scope for improvements is larger.

This research highlights the potential energy improvement that the cost-optimal analysis is able to provide in retrofit projects with respect to the baseline scenarios. The renovation procedure analyzed in this paper is not intended to be as single case-study as the obtained results can be spread to other similar projects in need of renovation. It stresses the importance of municipalities in the renovation of public buildings such as schools.

It also suggests further research effort on refurbishment optimization studies. Efficient control systems for air temperature, humidity, air quality and air change rate are among the fundamental solutions that should characterize schools in near future. School buildings should play a leading role towards the EU 20-20-20 goals for their capacity to spread a living style focused on environmental responsibility amongst future generations.

Acknowledgments: This work is part of a Collaboration Agreement (No 33436) between the University of Salento and the Joint Research Centre.

Author Contributions: All the authors carried out the research during its different phases, such as research design, methodology, development and analysis. They discussed the results and prepared the manuscript together according to the progress of study. In particular, Paolo Maria Congedo planned the work, Ilaria Zacà and Giuliano Tornese did the simulations with CasaClima software and did the analysis of results, Delia D'Agostino and Cristina Baglivo wrote the paper, Paolo Maria Congedo did the revision of the paper.

Conflicts of Interest: The authors declare no conflict of interest.

\begin{tabular}{ll}
\hline Nomenclature \\
\hline$V$ & volume at controlled temperature \\
REF & reference building \\
INS & insulation \\
PL & plaster \\
WI & window \\
$U$ & thermal transmittance $\left(\mathrm{W} / \mathrm{m}^{2} \mathrm{~K}\right)$ \\
GEN & generation system \\
EM & emission system \\
$c$ & specific heat capacity $(\mathrm{kJ} / \mathrm{kgK})$ \\
$d$ & total thickness (m) \\
VENT & ventilation system \\
SC & solar collector panels \\
PV & photovoltaic panels \\
CMV & controlled mechanical ventilation \\
DHW & domestic hot water \\
AHU & air handling unit \\
$q$ & air flow \\
SPF & specific power consumption \\
$t_{B}$ & daily service time \\
$P$ & thermal capacity \\
$T_{h / w}$ & design heating/water temperature \\
$T_{s t}$ & average storage temperature \\
$h_{s t}$ & daily hours with accumulation in temperature \\
\hline &
\end{tabular}




\begin{tabular}{|c|c|}
\hline \multicolumn{2}{|c|}{ Nomenclature } \\
\hline COP & coefficient of performance \\
\hline SEER & seasonal energy efficiency ratio \\
\hline No & number of panels \\
\hline$P_{\text {peak }}$ & peak power \\
\hline$f_{s}$ & azimuth \\
\hline$f_{n}$ & zenith \\
\hline $\mathrm{PE}$ & primary energy \\
\hline RES & renewable energy sources \\
\hline GC & global cost \\
\hline$t_{i}$ & insulating thickness \\
\hline$A_{N}$ & panel area \\
\hline$s$ & thickness of metal spacer \\
\hline$R_{d}$ & discount rate \\
\hline$R_{R}$ & real interest rate \\
\hline$R_{p}$ & rate of development of the price for products \\
\hline No Combo & Number of combinations \\
\hline Red. & Reduction \\
\hline \multicolumn{2}{|c|}{ Greek letters } \\
\hline$\lambda$ & design thermal conductivity $(\mathrm{W} / \mathrm{m} \cdot \mathrm{K})$ \\
\hline$\rho$ & nsity $\left(\mathrm{kg} / \mathrm{m}^{3}\right)$ \\
\hline$\eta$ & efficiency \\
\hline$\Psi$ & linear transmittance $(\mathrm{W} / \mathrm{mK})$ \\
\hline \multicolumn{2}{|l|}{ Subscripts } \\
\hline $\mathrm{w}$ & winter \\
\hline $\mathrm{f}$ & frame \\
\hline $\mathrm{w}$ & window \\
\hline e & emission \\
\hline d & distribution \\
\hline g & generation \\
\hline $\mathrm{r}$ & regulation \\
\hline$e, w$ & dhw emission \\
\hline$d, w$ & dhw distribution \\
\hline $\mathrm{s}, \mathrm{w}$ & dhw storage \\
\hline $\mathrm{v}, \mathrm{e}$ & external air flow \\
\hline $\mathrm{v}$, tot & total air flow \\
\hline$\theta_{\mathrm{w}, \mathrm{d}}$ & winter thermal recovery \\
\hline$\theta_{\mathrm{s}, \mathrm{d}}$ & summer thermal recovery \\
\hline $\mathrm{s}$ & storage \\
\hline $\mathrm{k}$ & panels \\
\hline \multicolumn{2}{|l|}{ Symbols } \\
\hline ר & complex amplitude \\
\hline- & mean value \\
\hline
\end{tabular}

\section{References}

1. Directive 2012/27/EU of the European parliament and of the council of 25 October 2012 energy on efficiency, amending Directives 2009/125/EC and 2010/30/EU and repealing Directives 2004/8/EC and 2006/32/EC. Off. J. Eur. Union 2012, 55. [CrossRef]

2. Directive 2010/31/EU of the European parliament and of the council of 19 May 2010 on the energy performance of buildings (recast). Off. J. Eur. Union 2010, 53. [CrossRef]

3. D'Agostino, D. Assessment of the progress towards the establishment of definitions of nearly zero energy buildings (nZEBs) in European Member States. J. Build. Eng. 2015, 1, 20-32. [CrossRef]

4. Hamdy, M.; Hasan, A.; Siren, K. A multi-stage optimization method for cost-optimal and nearly-zero-energy building solutions in line with the EPBD-recast 2010. Energy Build. 2013, 56, 189-203. [CrossRef] 
5. Kapsalaki, M.; Leal, V.; Santamouris, M. A methodology for economic efficient design of Net Zero Energy Buildings. Energy Build. 2011, 43, 3279-3288. [CrossRef]

6. Lu, Y.; Wang, S.; Shan, K. Design optimization and optimal control of grid-connected and standalone nearly/net zero energy buildings. Appl. Energy 2015, 155, 463-477. [CrossRef]

7. Eurostat. Final Energy Consumption by Sector. 2014. Available online: http:/ /epp.eurostat.ec.europa.eu/ portal/page/portal/statistics/search/database (accessed on 14 March 2016).

8. Concerted Action Energy Performance of Buildings Directive (CA EPBD). Concerted Action EPBD: Implementing the Energy Performance of Buildings Directive (EPBD). Information of the Joint Initiative of EU Member States and the European Commission. Available online: http://www.epbd-ca.eu/themes/costoptimum (accessed on 18 January 2016).

9. Commission Delegated Regulation (EU) No 244/2012 of 16 January 2012 Supplementing Directive 2010/31/EU of the European Parliament and of the Council on the Energy Performance of Buildings by Establishing a Comparative Methodology Framework for Calculating Cost-Optimal Levels of Minimum Energy Performance Requirements for Buildings and Building Elements. Off. J. Eur. Union 2012, 55. [CrossRef]

10. Guidelines Accompanying Commission Delegated Regulation (EU) No 244/2012 of 16 January 2012 supplementing Directive 2010/31/EU of the European Parliament and of the Council on the energy performance of buildings by establishing a comparative methodology framework for calculating cost-optimal levels of minimum energy performance requirements for buildings and building elements. Off. J. Eur. Union 2012, 55. [CrossRef]

11. Energy Performance of Buildings, Economic Evaluation Procedure for Energy Systems in Buildings; UNI EN 15459; European Committee for Standardization: Brussels, Belgium, 2007.

12. Energy Performance of Buildings; Part 1 (2014): Evaluation of energy need for space heating and cooling. Part 2 (2014): Evaluation of primary energy need and of system efficiencies for space. Part 3 (2010): Evaluation of primary energy and system efficiencies for space cooling. Part 4 (2012): Renewable energy and other generation systems for space heating and domestic hot water production heating, domestic hot water production, ventilation and lighting for non-residential buildings; Technical regulation UNI/TS 11300; Ente Italiano di Normazione: Milano, Italy.

13. Building Performance Institute Europe (BPIE). A Guide to Developing Strategies for Building Energy Renovation; Delivering Article 4 of the Energy Efficiency Directive; BPIE: Brussels, Belgium, 2013.

14. Barthelmes, V.M.; Becchio, C.; Bottero, M.C.; Corgnati, S.P. The influence of energy targets and economic concerns in design strategies for a residential nearly-zero energy building. Buildings 2014, 4, 937-962. [CrossRef]

15. Baglivo, C.; Congedo, P.M.; D’Agostino, D.; Zacà, I. Cost-optimal analysis and technical comparison between standard and high efficient mono-residential buildings in a warm climate. Energy 2015, 83, 560-575. [CrossRef]

16. Zacà, I.; D'Agostino, D.; Congedo, P.M.; Baglivo, C. Assessment of cost-optimality and technical solutions in high performance multi-residential buildings in the Mediterranean area. Energy Build. 2015, 102, 250-265. [CrossRef]

17. Congedo, P.M.; Baglivo, C.; D'Agostino, D.; Zacà, I. Cost-optimal design for nearly zero energy office buildings located in warm climates. Energy 2015, 91, 967-982. [CrossRef]

18. Nemry, F.; Uihlein, A.; Colodel, C.M.; Wetzel, C.; Braune, A.; Wittstock, B.; Hasan, I.; Kreißig, J.; Gallon, N.; Niemeier, S.; et al. Options to reduce the environmental impacts of residential buildings in the European Union-Potential and costs. Energy Build. 2010, 42, 976-984. [CrossRef]

19. Zinzi, M.; Agnoli, S.; Battistini, G.; Bernabini, G. Deep energy retrofit of the T.M. Plauto School in Italy-A five years experience. Energy Build. 2016, 126, 239-251. [CrossRef]

20. Garcia, D.A.; Cumo, F.; Tiberi, M.; Sforzini, V.; Piras, G. Cost-Benefit Analysis for Energy Management in Public Buildings: Four Italian Case Studies. Energies 2016, 9, 522. [CrossRef]

21. Ascione, F.; Bianco, N.; de Masi, R.F.; Rossi, F.D.; Vanoli, G.P. Energy refurbishment of existing buildings through the use of phase change materials: Energy savings and indoor comfort in the cooling season. Appl. Energy 2014, 113, 990-1007. [CrossRef]

22. Evangelisti, L.; Guattari, C.; Gori, P. Energy Retrofit Strategies for Residential Building Envelopes: An Italian Case Study of an Early-50s Building. Sustainability 2015, 7, 10445-10460. [CrossRef] 
23. Patiño-Cambeiro, F.; Armesto, J.; Patiño-Barbeito, F.; Bastos, G. Perspectives on near ZEB Renovation Projects for Residential Buildings: The Spanish Case. Energies 2016, 9, 628. [CrossRef]

24. Pareira, L.D.; Raimondo, D.; Corgnati, S.P.; da Silva, M.G. Energy consumption in schools-A review. Renew. Sustain. Energy Rev. 2014, 40, 911-922. [CrossRef]

25. Bonazzi, G.; Lotti, M. Evaluation of Investment in Renovation to Increase the Quality of Buildings: A Specific Discounted Cash Flow (DCF) Approach of Appraisal. Sustainability 2016, 8, 268. [CrossRef]

26. School of the Future. Towards Zero Emission with High Performance Indoor Environment 2010-2015. FP7 EU Collaborative Project Ee B.ENERGY: 2010.8.1-2: Demonstration of Energy Efficiency through Retrofitting of Buildings. 2010. Available online: http://cordis.europa.eu/programme/rcn/12971_en.html (accessed on 20 April 2016).

27. Ma, Z.; Cooper, P.; Daly, D.; Ledo, L. Existing building retrofits: Methodology and state-of-the-art. Energy Build. 2012, 55, 889-902. [CrossRef]

28. Buildings Performance Institute Europe (BPIE). Implementing the Cost-Optimal Methodology in EU Countries; BPIE: Bruxelles, Belgium, 2013. Available online: http://bpie.eu/cost_optimal_methodology.html (accessed on 5 April 2016).

29. Stocker, E.; Tschurtschenthaler, M.; Schrott, L. Cost-optimal renovation and energy performance: Evidence from existing school buildings in the Alps. Energy Build. 2015, 100, 20-26. [CrossRef]

30. Corrado, V.; Ballarini, I.; Paduos, S. Sviluppo Della Metodologia Comparativa Cost-Optimal Secondo Direttiva 2010/31/UE. 2013. Available online: http:/ / www.enea.it/it/Ricerca_sviluppo/documenti/ricercadi-sistema-elettrico/edifici-pa/2012/rds-2013-144.pdf (accessed on 12 October 2016). (In Italian)

31. Armani, R.; Pietrobon, M.; Pagliano, L. Definizione dei Parametri per L'ottimizzazione di Interventi di Riqualificazione in Considerazione del Fattore Costi/Benefici; Report RdS/PAR2013/114; Report Ricerca di Sistema Elettrico Accordo di Programma Ministero dello Sviluppo Economico; ENEA: Kista, Sweden, 2014. (In Italian)

32. Rapporto 2009 Sulla Scuola in Italia, Fondazione Giovanni Agnelli Dicembre 2008. Available online: http://www.documentazione.info/rapporto-sulla-scuola-italiana-gli-insegnanti (accessed on 2 March 2016).

33. JRC Science and Policy Report, Energy Renovation: The Trump Card for the New Start for Europe. 2015. Available online: http://iet.jrc.ec.europa.eu/energyefficiency/system/tdf/eur26888_buildingreport_online. pdf?file=1\&type=node\&id=9069 (accessed on 29 January 2016).

34. De Santoli, L.; Fraticelli, F.; Fornari, F.; Calice, C. Energy performance assessment and retrofit strategies in public school buildings in Rome. Energy Build. 2014, 68, 196-202. [CrossRef]

35. Corgnati, S.P.; Corrado, V.; Filippi, M. A method for heating consumption assessment in existing buildings: A field survey concerning 120 Italian schools. Energy Build. 2008, 40, 801-809. [CrossRef]

36. Guida ANIT. La Legislazione per il Risparmio Energetico e L'acustica Degli Edifici; TEP srl: Milan, Italy, 2015; Volume 1. (In Italian)

37. Dall'O', G.; Bruni, E.; Panza, A. Improvement of the sustainability of existing school buildings according to the leadership in energy and environmental design (LEED) ${ }^{\circledR}$ protocol: A case study in Italy. Energies 2013, 6 , 6487-6507. [CrossRef]

38. Marco, C.; Gaetano, F. Indagine Sui Consumi Degli Edifici Pubblici (Direzionale e Scuole) e Potenzialità Degli Interventi di Efficienza Energetica. 2009. Available online: http://www.enea.it/it/Ricerca_sviluppo/ documenti/ricerca-di-sistema-elettrico/condizionamento/rse165.pdf (accessed on 14 December 2015).

39. Italian Energy Efficiency Action Plan. 2014. p. 168. Available online: http://ec.europa.eu/energy/en/ topics/energy-efficiency/energy-efficiency-directive/national-energy-efficiency-action-plans (accessed on 24 February 2016).

40. EU FP7 Demonstration Project School of the Future (260102). Available online: www.school-of-the-future.eu (accessed on 29 March 2016).

41. IEE Project ZEMeds (IEE/12/711). Available online: http://www.zemeds.eu (accessed on 10 February 2016).

42. D'Agostino, D.; Congedo, P.M. CFD modeling and moisture dynamics implications of ventilation scenarios in historical buildings. Build. Environ. 2014, 79, 181-193. [CrossRef]

43. D'Agostino, D.; Congedo, P.M.; Cataldo, R. Computational fluid dynamics (CFD) modeling of microclimate for salts crystallization control and artworks conservation. J. Cult. Herit. 2014, 15, 448e57. [CrossRef]

44. Marco, B.; Vincenzo, C.; Andrea, G.; Francesco, P. Building simulation software BSA2015. In Proceedings of the 2nd IBPSA-Italy Conference of Building Simulation Applications, Bolzano, Italy, 4-6 February 2015. 
45. Thermal Performance of Buildings. Heat Transfer via the Ground. Calculation Methods; EN ISO 13370; Technical Committee, ISO/TC 163; International Organization for Standardization: Geneva, Switzerland, 2007.

46. European Commission Recommendation (EU) 2016/1318 of 29 July 2016 on Guidelines for the Promotion of Nearly Zero-Energy Buildings and Best Practices to Ensure that, by 2020, All New Buildings Are Nearly Zero-Energy Buildings. Off. J. Eur. Union 2016. L 208/46. Available online: http://eur-lex.europa.eu/ legal-content/EN/TXT/?uri=uriserv:OJ.L_.2016.208.01.0046.01.ENG\&toc=OJ:L:2016:208:TOC (accessed on 9 August 2016).

47. JRC Synthesis Report on National Plans for NZEB. 2016. Available online: http://iet.jrc.ec.europa.eu/ energyefficiency/publications/all (accessed on 21 April 2016).

(C) 2016 by the authors; licensee MDPI, Basel, Switzerland. This article is an open access article distributed under the terms and conditions of the Creative Commons Attribution (CC-BY) license (http://creativecommons.org/licenses/by/4.0/). 